Riparian Vegetation Response to the March 2008 ShortDuration, High-Flow Experiment-Implications of Timing and Frequency of Flood Disturbance on Nonnative Plant Establishment Along the Colorado River Below Glen Canyon Dam

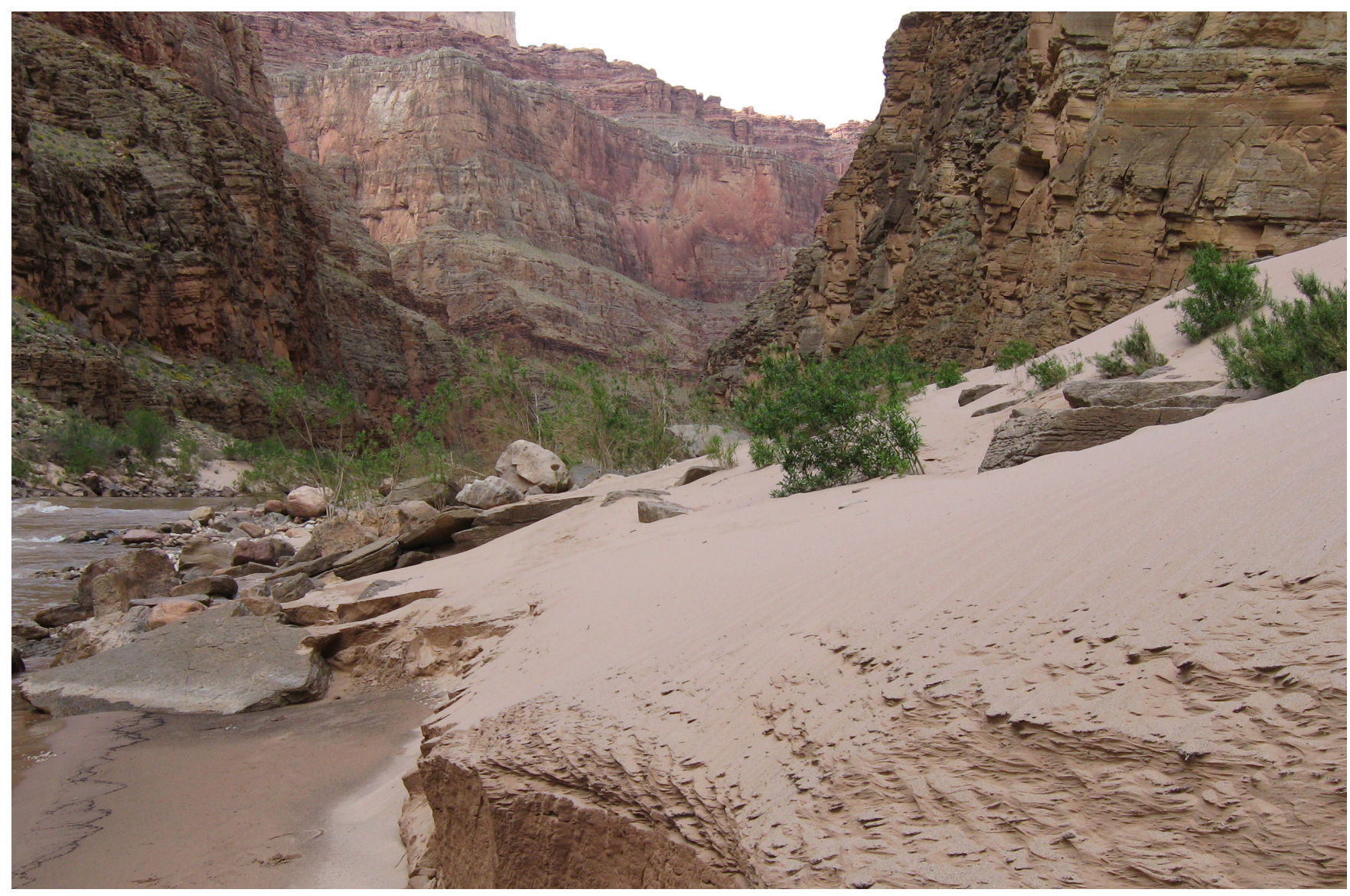

Open-File Report 2010-1022 
Cover: Photograph of Colorado River sandbar taken on March 30, 2008, at Olo Canyon, which is 146 miles downstream of Lees Ferry, Arizona. Riparian vegetation on this sandbar was buried by several meters of sand during the March 2008 high-flow experiment. (Photograph by B. Ralston, U.S. Geological Survey.) 


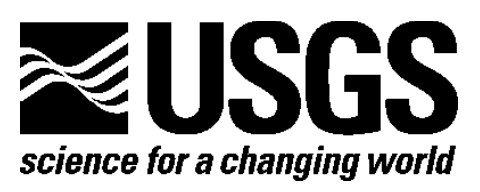

Riparian Vegetation Response to the March 2008 ShortDuration, High-Flow Experiment-Implications of Timing and Frequency of Flood Disturbance on Nonnative Plant Establishment Along the Colorado River Below Glen Canyon Dam

By Barbara E. Ralston

Open-File Report 2010-1022

U.S. Department of the Interior

U.S. Geological Survey 


\section{U.S. Department of the Interior \\ KEN SALAZAR, Secretary}

\section{U.S. Geological Survey \\ Marcia K. McNutt, Director}

U.S. Geological Survey, Reston, Virginia: 2010

For product and ordering information:

World Wide Web: http://www.usgs.gov/pubprod

Telephone: 1-888-ASK-USGS

For more information on the USGS-the Federal source for science about the Earth,

its natural and living resources, natural hazards, and the environment:

World Wide Web: http://www.usgs.gov

Telephone: 1-888-ASK-USGS

Suggested citation:

Ralston, Barbara E., 2010, Riparian vegetation response to the March 2008 short-duration, high-flow experimentimplications of timing and frequency of flood disturbance on nonnative plant establishment along the Colorado River below Glen Canyon Dam: U.S. Geological Survey Open-File Report 2010-1022, 30 p. [http://pubs.usgs.gov/of/2010/1022/].

Any use of trade, product, or firm names is for descriptive purposes only and does not imply endorsement by the U.S. Government.

Although this report is in the public domain, permission must be secured from the individual copyright owners to reproduce any copyrighted material contained within this report. 


\section{Contents}

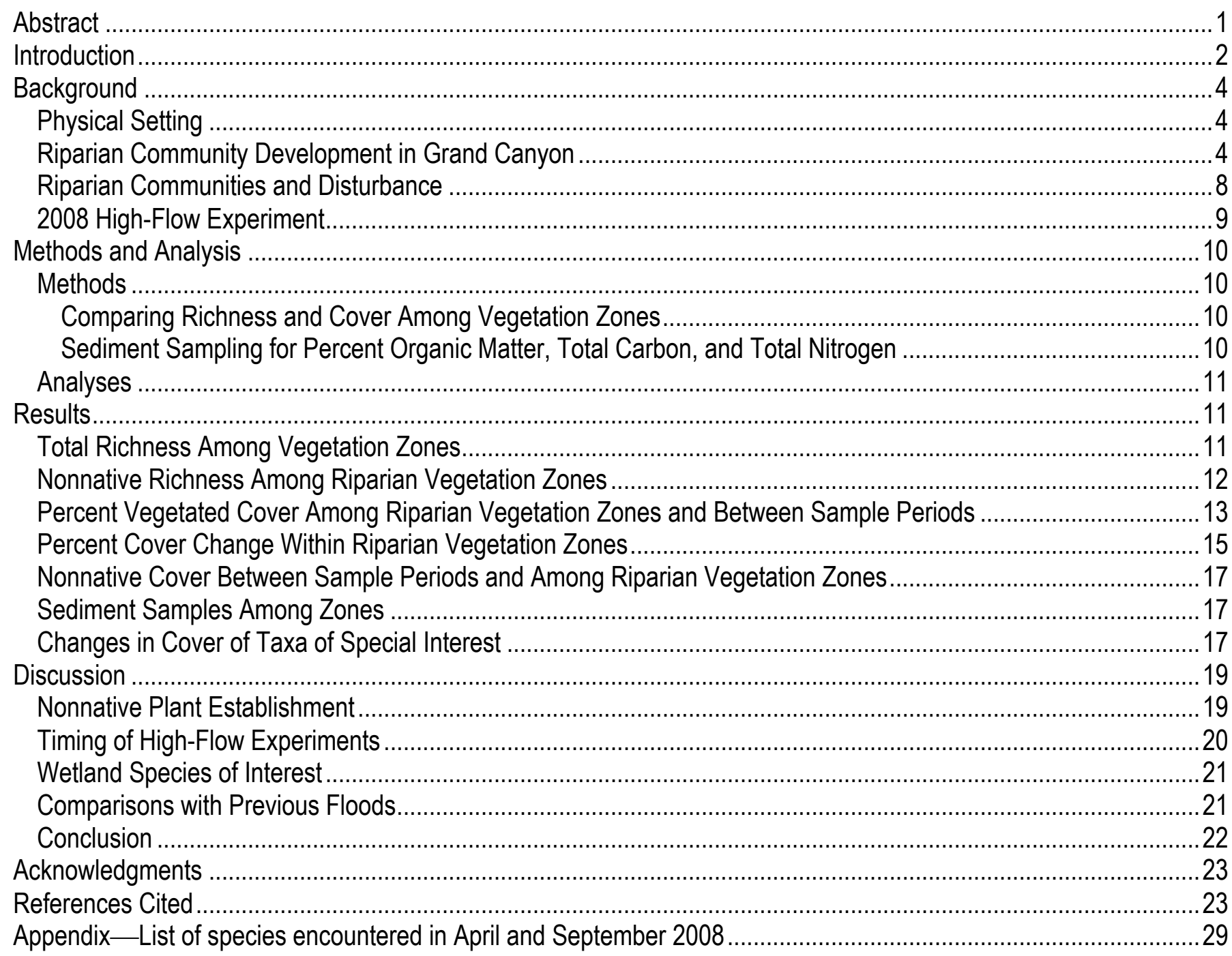

\section{Figures}

1. Map of the study area with Glen Canyon Dam, Lees Ferry, and the Little Colorado River confluence identified

2. Instantaneous discharge recorded at the Lees Ferry gage, Ariz., from 1921 through September $2000 \ldots \ldots \ldots . . . .6$

3. Cross-sectional diagram of four post-dam riparian vegetation zones, zone abbreviations, and associated stage elevations found along the Colorado River corridor in Grand Canyon, Ariz.

4. Bar graph showing mean total species richness among riparian vegetation zones in Grand Canyon, Ariz., in April and September 2008

5. Bar graph showing mean nonnative species richness in riparian vegetation zones in Grand Canyon, Ariz., in April and September 2008

6. Bar graphs showing mean percent vegetative cover in riparian vegetation zones in Grand Canyon, Ariz., in April and September 2008 ................................................................................................ 14

7. Bar graph showing mean percent vegetative cover in riparian vegetation zones in Grand Canyon, Ariz., in April and September 2008 
8. Bar graph showing mean percent vegetative cover of plant categories contributing to significant cover changes within the Hydro Riparian Zone and the Lower Riparian Zone in Grand Canyon, Ariz., in April and September 2008.

9. Mean percent vegetative cover of five woody riparian species in the Lower Riparian Zone in Grand Canyon, Ariz., in April and September 2008.

10. Bar graph showing mean percent vegetative cover of nonnative plants in riparian vegetation zones in Grand Canyon, Ariz., in April and September in 2008.

11. Mean percent cover of vegetation categories in riparian vegetation zones in Grand Canyon, Ariz., in April and September 2008.

12. Bar graph of five wetland taxa in April and September 2008 for all riparian vegetation zones in Grand Canyon, Ariz.

\section{Conversion Factors}

SI to Inch/Pound

\begin{tabular}{lcl}
\hline \multicolumn{1}{c}{ Multiply } & By & \multicolumn{1}{c}{ To obtain } \\
\hline meter $(\mathrm{m})$ & Length & \\
kilometer $(\mathrm{km})$ & 3.281 & foot $(\mathrm{ft})$ \\
& 0.6214 & mile $(\mathrm{mi})$ \\
\hline square meter $\left(\mathrm{m}^{2}\right)$ & Area & \\
\hline & 10.76 & square foot $\left(\mathrm{ft}^{2}\right)$ \\
\hline cubic meter $\left(\mathrm{m}^{3}\right)$ & Volume & \\
\hline
\end{tabular}

Temperature in degrees Celsius $\left({ }^{\circ} \mathrm{C}\right)$ may be converted to degrees Fahrenheit $\left({ }^{\circ} \mathrm{F}\right)$ as follows: ${ }^{\circ} \mathrm{F}=\left(1.8 \times{ }^{\circ} \mathrm{C}\right)+32$

Temperature in degrees Fahrenheit $\left({ }^{\circ} \mathrm{F}\right)$ may be converted to degrees Celsius $\left({ }^{\circ} \mathrm{C}\right)$ as follows:

${ }^{\circ} \mathrm{C}=\left({ }^{\circ} \mathrm{F}-32\right) / 1.8$ 


\title{
Riparian Vegetation Response to the March 2008 Short- Duration, High-Flow Experiment-Implications of Timing and Frequency of Flood Disturbance on Nonnative Plant Establishment along the Colorado River below Glen Canyon Dam
}

\author{
By Barbara E. Ralston
}

\begin{abstract}
Riparian plant communities exhibit various levels of diversity and richness. These communities are affected by flooding and are vulnerable to colonization by nonnative species. Since 1996, a series of three high-flow experiments (HFE), or water releases designed to mimic natural seasonal flooding, have been conducted at Glen Canyon Dam, Ariz., primarily to determine the effectiveness of using high flows to conserve sediment, a limited resource. These experiments also provide opportunities to examine the susceptibility of riparian plant communities to nonnative species invasions. The third and most recent HFE was conducted from March 5 to 9, 2008, and scientists with the U.S. Geological Survey's Grand Canyon Monitoring and Research Center examined the effects of high flows on riparian vegetation as part of the overall experiment. Total plant species richness, nonnative species richness, percent plant cover, percent organic matter, and total carbon measured from sediment samples were compared for Grand Canyon riparian vegetation zones immediately following the HFE and 6 months later. These comparisons were used to determine if susceptibility to nonnative species establishment varied among riparian vegetation zones and if the timing of the HFE affected nonnative plant establishment success.

The 2008 HFE primarily buried vegetation rather than scouring it. Percent nonnative cover did not differ among riparian vegetation zones; however, in the river corridor affected by Glen Canyon Dam operations, nonnative species richness showed significant variation. For example, species richness was significantly greater immediately after and 6 months following the HFE in the hydrologic zone farthest away from the shoreline, the area that represents the oldest riparian zone within the post-dam riparian area. In areas closer to the river channel, tamarisk (Tamarix ramosissima $X$ chinensis) seedling establishment occurred ( $<2$ percent cover) in 2008 but not to the extent reported in either 2000, a year when experimental summer flows coincided with tamarisk seed production, or in 1986, a year following several years of sustained flooding. The results from the $2008 \mathrm{HFE}$ suggest that riparian vegetation zones subject to intermittent disturbance and near the river under normal dam operations are more susceptible to nonnative species introductions following a disturbance.

This study also finds that the timing of an HFE affects the types of species that can become established. For example, HFEs conducted in March are associated with reduced tamarisk seedling establishment compared to disturbances later in the season. Additionally, early season, short-duration flooding that results in vegetation burial may favor clonal species. Along the Colorado River many of
\end{abstract}


these clonal species are native; these species include arrowweed (Pluchea sericea), coyote willow (Salix exigua), and rivercane (Phragmites australis).

\section{Introduction}

The construction of dams along the Colorado River occurred throughout the 20th century (Reisner, 1993) for the purposes of flood control, water storage and delivery, and power generation. Completed in 1963, Glen Canyon Dam lies approximately $24 \mathrm{~km}$ upstream of Grand Canyon National Park, Ariz., on the Colorado River just south of the Arizona-Utah border (fig. 1). Because the dam stops most sediment moving downstream, its presence has resulted in erosion and shrinkage of river sandbars in Grand Canyon (Schmidt and others, 2004; Wright and others, 2005). Fewer and smaller sandbars mean smaller camping beaches for visitors to use (Kaplinski and others, 2005), continued erosion of cultural sites (Hereford and others, 1993; Fairley, 2005), and possibly less habitat for native fish, including the endangered humpback chub (Gila cypha). More recently, researchers have recognized the role flooding has in maintaining the ecological integrity of riverine systems (Poff and others, 1997; Molles and others, 1998; Stromberg, 2001)

In an effort to restore sandbars and related habitat and to comply with its responsibilities under the Grand Canyon Protection Act of 1992, the Department of the Interior conducted a series of three high-flow experiments (HFEs), or water releases designed to mimic natural seasonal flooding, in 1996, 2004, and 2008. A primary purpose of reintroducing flooding to the Colorado River below Glen Canyon Dam was to evaluate the utility of flooding as a tool to conserve sediment by moving sediments stored in eddies to higher areas above annual operating hydrographs (Webb and others, 1999; Rubin and others, 2002). These experiments also provide opportunities to examine how HFEs affect the susceptibility of riparian plant communities to nonnative species invasions. 


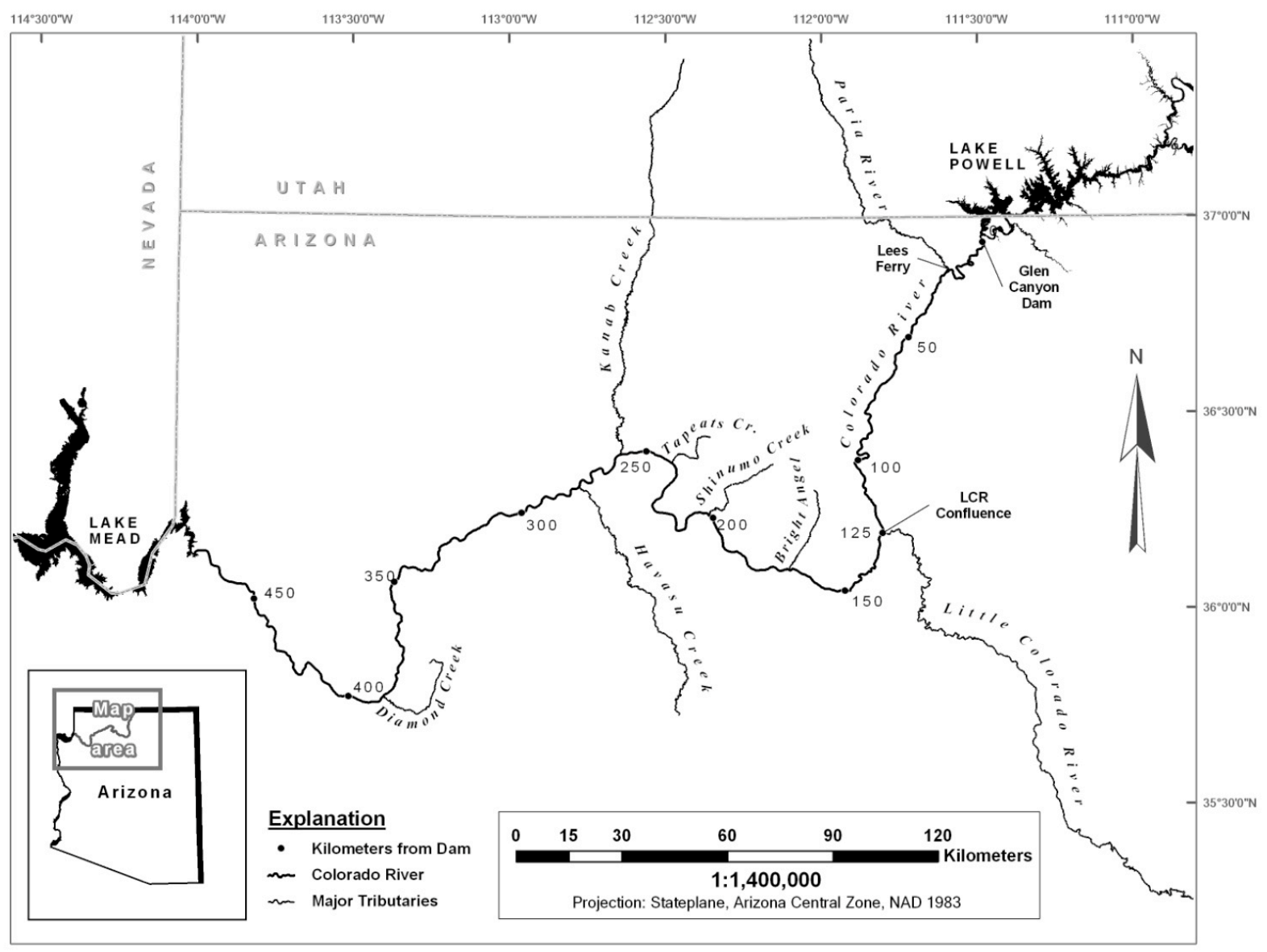

Figure 1. Map of the study area with Glen Canyon Dam, Lees Ferry, and the Little Colorado River confluence identified. River kilometers starting at Glen Canyon Dam are listed in 50-km segments.

The third and most recent HFE was conducted from March 5 to 9, 2008, and scientists with the U.S. Geological Survey's Grand Canyon Monitoring and Research Center examined the effects of high flows on riparian vegetation in a 472-km section of the Colorado River stretching from below Glen Canyon Dam to the mouth of Lake Mead, including Grand Canyon National Park (fig. 1) as part of the overall experiment. Total plant species richness, nonnative plant species richness, percent plant cover, percent organic matter, and percent total carbon measured from sediment samples were compared for Grand Canyon riparian vegetation zones immediately following the HFE and 6 months later. This study addresses two questions about nonnative plant species invasions in a regulated river system following a disturbance. First, how does frequency of disturbance within the riparian zone of a regulated system affect susceptibility to nonnative species invasions? Second, how does timing of an HFE affect the types and extent of nonnative species invasions? Identifying which nonnative species may be favored by the timing of an HFE and the locations within the riparian community that are potentially more susceptible to nonnative invasions can help resource managers better understand factors affecting riparian system susceptibility to nonnative species establishment. When considering 
nonnative species control measures and limited financial resources, the identification of susceptible areas provides managers the opportunity to act in a pragmatic, focused manner.

\section{Background}

\section{Physical Setting}

The Colorado River through Glen, Marble, and Grand Canyons is a bedrock constrained river channel in which debris flows from tributaries create pool and drop-type constrictions (Schmidt and Graf, 1990). Eddies upstream of tributaries and immediately downstream of constrictions create debris-fan eddy complexes where sediments can become deposited following sediment inputs and depositional events (high discharges) (Rubin and others, 1990). These areas are associated with large sand deposits and are often used for recreational camping. Other depositional areas are channelmargin deposits that form between tributaries and their associated sandbars. Channel-margin deposits are small and typically associated with talus slopes, sandstone, limestone, or metamorphic/granitic cliff walls. All of these areas are prone to sediment deposition following tributary inputs and flooding. Sediment in the study area is a limited resource because tributaries below Glen Canyon Dam deliver less than 10 percent of the historical annual sediment load of the Colorado River (Andrews, 1991; Wright and others, 2005). Yet, sediment is a primary component of the Colorado River ecosystem, providing a substrate for riparian and wetland plants and benthic invertebrates (Stevens and others, $1995,1997)$ that in turn supports aquatic and terrestrial biota. Tributary inputs deliver sediment and organic material that can form substrate and provide nutrients to riparian and aquatic systems (Parnell and others, 1999).

Silt and sand are the primary substrate for vegetation along the river corridor, although some plants grow only on rocks. The geomorphology of the canyon and the annual operations of the dam affect the depositional qualities of the substrate, which affects plant distributions along the corridor. Rather than forming a continuous ribbon of vegetation throughout the corridor, canyon morphology and available sediment below Glen Canyon Dam results in a riparian community that has a patchy distribution along the river corridor. The vegetation patches also vary in width and density of cover.

In general, under normal dam operations, fine silt and clay particles that flow in from tributaries are some of the first sediments that are exported from the system (Topping and others, 2000). The finer grained sediments that are retained in the system deposit in low-velocity environments associated with an eddy or other low-profile shorelines with slow currents. These environments are areas where wetland species adapted to low-oxygen conditions, high-inundation frequency, and higher silt concentrations are found along the river corridor (Stevens, 1989a; Stevens and others, 1995). Sand deposits made up of more coarse-grained sands are found at higher stage elevations within debris-fan eddy complexes and along channel margins. During a flood, sand and silt deposited in eddies are reworked and deposited on sandbars. Erosion occurs with any high-discharge event, but aggradation of sand above annual operating discharges can occur if the sediment inputs are greater than the existing sandbar volumes (Rubin and others, 2002; Wright and others, 2008). In general, the Colorado River below Glen Canyon Dam is a sediment losing system (Schmidt and others, 2004; Wright and others, 2008).

\section{Riparian Community Development in Grand Canyon}

Before Glen Canyon Dam, the Colorado River corridor in Grand Canyon was subject to yearly seasonal flooding of variable magnitude. The average 2-year return flood volume was 2,406 $\mathrm{m}^{3} / \mathrm{s}$ and 
typically had a slow receding hydrograph that extended through the summer months and was followed by low flows through the winter months (Topping and others, 2003). The pre-dam riparian vegetation was composed primarily of woody riparian species (Clover and Jotter, 1944; Turner and Karpiscak, 1980; Carothers and Brown, 1991), including mesquite (Prosopis glandulosa), seepwillow (Baccharis emoryi), tamarisk (Tamarix sp.), and arrowweed (Pluchea sericea). There were some lower lying riparian and wetland species, such as coyote willow (Salix exigua), Goodings willow (Salix goodingii), cattails (Tyhpa latifolia), and common reed (Phragmites australis), but these species were sparsely distributed along the river corridor in more floodplain-type geomorphology found near Lees Ferry (fig. 1) or farther downstream in western Grand Canyon (Clover and Jotter, 1944; Webb and others, 2002). Because of annual high-discharge flooding in the pre-dam era, the woody riparian species persisted along the high flood line, while plants occupying areas closer to the shoreline were more ephemeral (Clover and Jotter, 1944).

The operations of Glen Canyon Dam changed the seasonal hydrologic pattern to one that fluctuated daily and shifted high-discharge months to coincide with power demands (June to September and December to February) (Korman and others, 2004). For the first 30 years following the completion of the dam, the seasonal peak flows of the Colorado River below Glen Canyon Dam were reduced by more than 50 percent, from $2,406 \mathrm{~m}^{3} / \mathrm{s}$ to $877 \mathrm{~m}^{3} / \mathrm{s}$. The reduced discharges exposed areas below the pre-dam annual flood line, and these exposed areas allowed more permanent plant colonization and establishment. The base flow during this time could be as low as $28 \mathrm{~m}^{3} / \mathrm{s}$, with daily fluctuations up to $877 \mathrm{~m}^{3} / \mathrm{s}$. In some narrower sections of the river corridor such daily fluctuations would result in $>4 \mathrm{~m}$ vertical change in stage discharge (Hazel and others, 2006). The riparian vegetative community along the river corridor changed in response to dam operations.

Public concern about the impacts of dam operations on resources resulted in operational changes to Glen Canyon Dam in the 1990s (U.S. Department of the Interior, 1995, 1996), including an interim flow period from 1991 to 1995 , which was studied as part of the effort to prepare the Operation of Glen Canyon Dam Final Environmental Impact Statement (U.S. Department of the Interior, 1995). The Record of Decision for the environmental impact statement was signed in 1996 (U.S. Department of the Interior, 1996) and implemented operation changes that included reducing daily fluctuations relative to base flow. Specifically, under the Record of Decision, dam releases fluctuate up to $226 \mathrm{~m}^{3} / \mathrm{s}$ daily and base flow is generally between $141 \mathrm{~m}^{3} / \mathrm{s}$ and $226 \mathrm{~m}^{3} / \mathrm{s}$ throughout the year, except in the summer when discharge increases and base flow correspondently increases (fig. 2). 


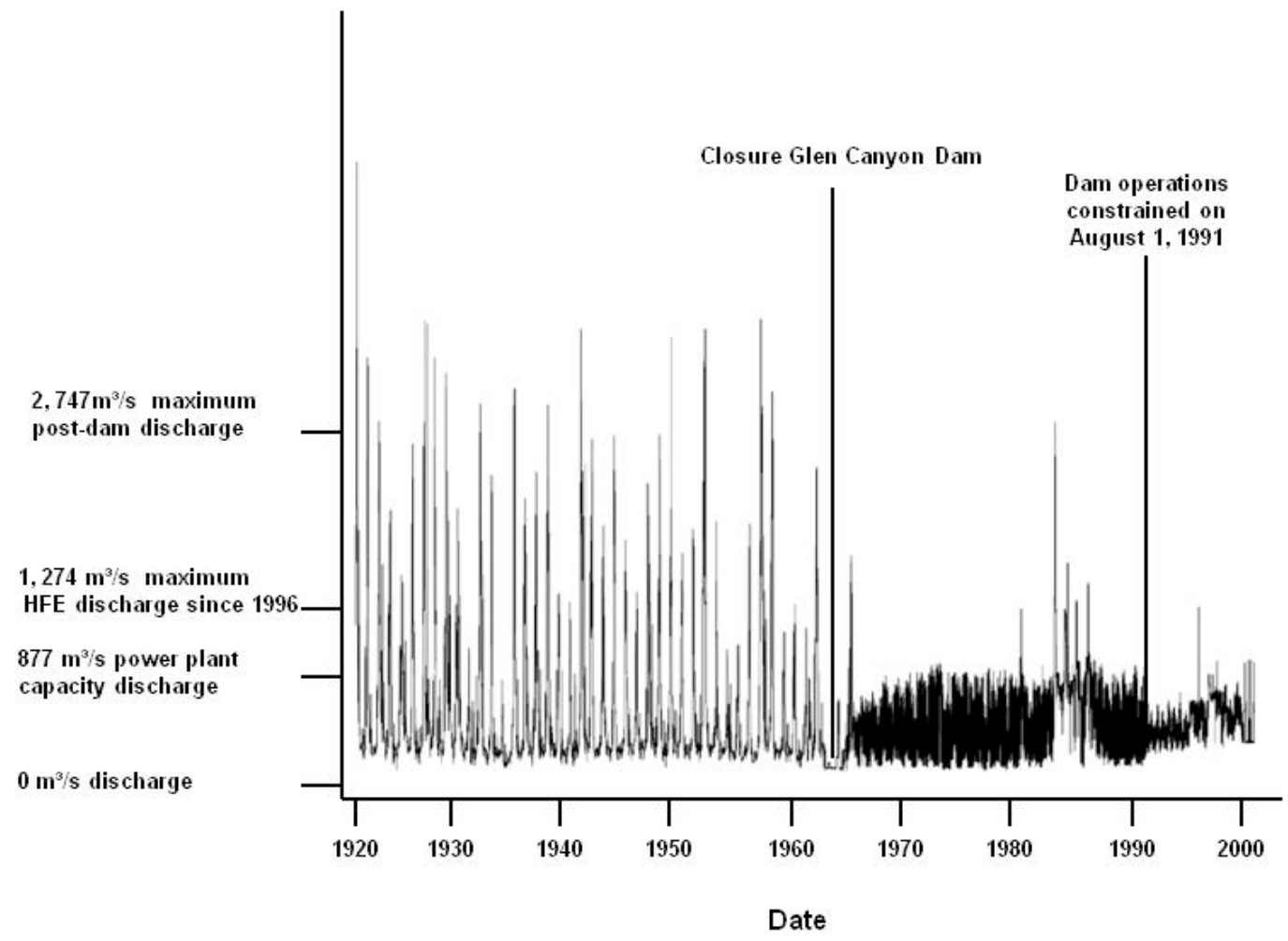

Figure 2. Instantaneous discharge recorded at the Lees Ferry gage, Ariz., from 1921 through September 2000. Vertical axis highlights stage elevations that are associated with post-dam operations. Note the increased base flows that began in the 1990s as the result of operational changes at Glen Canyon Dam. Figure modified from Topping and others (2003).

Glen Canyon Dam has changed the riparian zone in the river corridor below it from one restricted to the historical high-water flood line to one that has expanded shoreward and includes riparian and wetland species (Turner and Karpiscak, 1980; Carothers and Brown, 1991; Stevens and others, 1995). The increased year-round water availability and reduced flood frequency resulting from the dam construction and subsequent operations promoted riparian vegetation expansion throughout the Colorado River corridor (Turner and Karpiscak, 1980; Webb and others, 2002). Dam-related expansion of the riparian plant community included native species (for example, coyote willow and cattails) and nonnative species (for example, tamarisk). Tamarisk is now recognized as a hybrid swarm (Gaskin and Shaal, 2002), the hybridization of at least two distinct species.

The persistent pre-dam riparian community was an intermittent band of vegetation dominated by woody riparian species, whereas the post-dam riparian community is stratified in width, cover, richness, and composition (Carothers and Brown, 1991) and varies in disturbance frequency. As in other riparian systems, species groups fall out along a hydrological gradient, with wetland species found closest to the shoreline and species adapted to drier conditions found further upslope (Nilsson and others, 1989; Stevens and others, 1995; Tabacchi and others, 1998; Lite and others, 2005). Operational changes in the mid-1990s (U.S. Department of the Interior, 1995) that restricted daily fluctuations resulted in continued expansion of vegetation (Waring, 1995), further hydrologic 
stratification (Ralston, 2005; Kearsley, 2006), reduced disturbance frequency above $708 \mathrm{~m}^{3} / \mathrm{s}$ discharges, and additional organic litter accumulation.

Tamarisk that was present along the corridor before dam construction (Clover and Jotter, 1944) quickly occupied and dominated the exposed sites. There are multiple reasons for the success of tamarisk in regulated river systems (Stromberg, 1998; Cooper and others, 2003), including, but not limited to, the availability of unoccupied, unshaded areas for seedling establishment (Stevens and Waring, 1986; Sher and Marshall, 2003). Regulated rivers also provide late summer water that would not have been available before regulation, and this shift in water availability coincides with tamarisk seed production, which occurs out of phase with native seed production. For example, native plants such as Goodings willow produce seeds in late spring while other native plants such as arrowweed and seepwillow produce their seeds in the late summer or early fall (Stevens, 1989b). Although tamarisk was likely a dominant constituent of the riparian community in Grand Canyon before the closure of Glen Canyon in 1963, as it was in the upper Colorado River Basin (Clover and Jotter, 1944; Birken and Cooper, 2006), by 1980 tamarisk was one of the dominant woody species along the river corridor (Turner and Karpiscak, 1980; Carothers and Brown, 1991).

The relatively stable post-dam hydrograph also promoted the expansion of fluvial wetlands throughout the river corridor (Stevens and others, 1995). The riparian species and obligate wetland that were previously restricted to uncommon floodplain habitats were able to colonize other types of low-velocity habitats, including return channels and channel margins. Fine-grain sediment (silts and clays) collected in these areas and formed a lower zone of plant species within the post-dam riparian community that was subject to daily inundation. The assemblage that established in this lower zone included native plants such as cattails and common reed, sedges (Carex sp.), rushes (Juncus sp.), bulrushes (Schoenoplectus sp.), and nonnative plants such as bentgrass (Agrostis stolonifera), rabbitfoot grass (Polypogon monospeliensis), and common plantain (Plantago major). The 1980s were also notable for multiple years of extensive summer flooding that exported sediment (Schmidt and others, 2004) and removed extensive vegetation below discharges of 1,415 $\mathrm{m}^{3} / \mathrm{s}$ (Stevens and Waring, 1986).

Post-dam riparian vegetation, which emerged as the result of the initial operation of Glen Canyon Dam and responded to operational changes that occurred since 1991, can be divided into four zones (fig. 3). Starting closest to shore, those plants occupying stage elevations between base flow and the average annual daily maximum discharge (226 to $\left.566 \mathrm{~m}^{3} / \mathrm{s}\right)$ exist within the Hydro Riparian Zone (HRZ). The next zone, the Lower Riparian Zone (LRZ), consists of the stage elevation above the average annual maximum and up to powerplant capacity (566 to $877 \mathrm{~m}^{3} / \mathrm{s}$ ). This zone was most exposed following implementation of interim flows in 1991 and is subject to disturbance in years of high-volume delivery and experimental habitat-maintenance flows. The Middle Riparian Zone (MRZ) is a zone of vegetation between powerplant capacity, $877 \mathrm{~m}^{3} / \mathrm{s}$, and $1,277 \mathrm{~m}^{3} / \mathrm{s}$, which is the maximum discharge associated with experimental high flows implemented since 1996 (Webb and others, 1999; Patten and Stevens, 2001). Above the $1,277 \mathrm{~m}^{3} / \mathrm{s}$ stage elevation is the Upper Riparian Zone (URZ), which includes the pre-dam and post-dam riparian vegetation that has not been subject to flood disturbance since 1986 (Stevens and Waring, 1986; Carothers and Brown; 1991). 


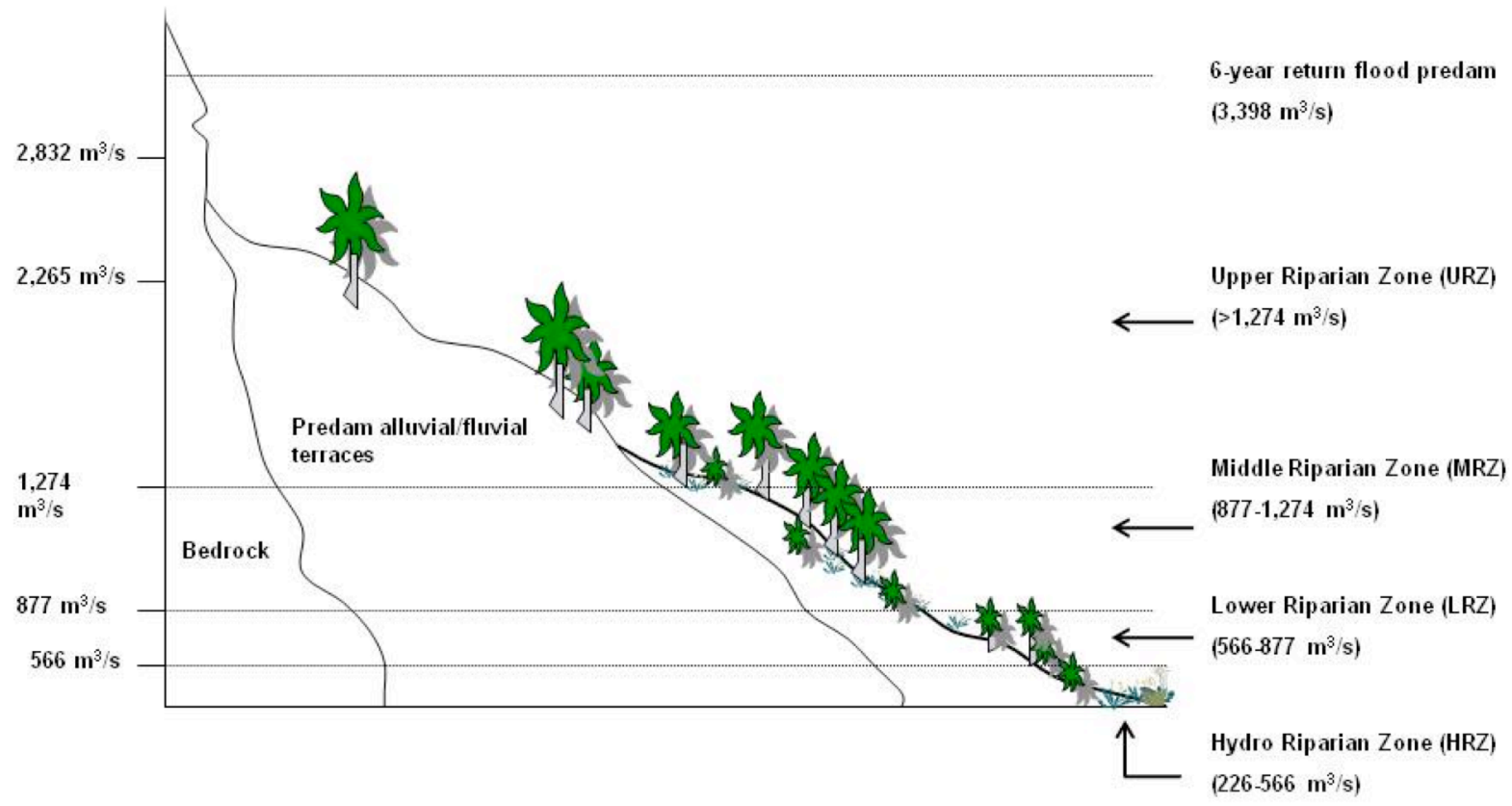

Figure 3. Cross-sectional diagram of four post-dam riparian vegetation zones, zone abbreviations, and associated stage elevations found along the Colorado River corridor in Grand Canyon, Ariz.

\section{Riparian Communities and Disturbance}

Among vegetation community types, riparian communities are considered highly susceptible to nonnative species introductions and expansions because of the persistent disturbance regime associated with seasonal hydrologic variability and introduced seed sources from drainage basins (Graf, 1978; Thébaud and Debussche, 1991; Merritt and Wohl, 2002, 2006; Naiman and others, 2005). Disturbance is a primary forcing variable in riparian community formation and development (Franz and Bazzaz, 1977; Malanson, 1993; Hupp and Osterkamp, 1996; Naiman and Decamps, 1997; Tabacchi and others, 1998). In turn, the magnitude and frequency of disturbance affects species richness, diversity, and structural complexity. Besides disturbance, water availability, which can be affected by daily and annual patterns of stream discharge and soil porosity, is a driver in riparian community structure and diversity (Stevens and others, 1995; Tabacchi and others, 1998; Lite and others, 2005). Surface water availability and absorptive properties of soils influence the distance from the shore that riparian plants, including obligate (plants found in wetlands 99 percent of the time) and facultative (plants found in wetlands 67-99 percent of the time) wetland plants, occur. Disturbance magnitude and frequency in combination with hydrological gradients within riparian communities result in a stratified community assemblage that varies in richness and structural complexity (Tabacchi and others, 1998; Lite and others, 2005; Beauchamp and Stromberg, 2008). Rather than viewing riparian communities as a single entity (for example, riparian versus nonriparian), the heterogeneous nature of riparian systems creates a variable landscape of species richness and diversity that can affect susceptibility to invasive species following disturbance.

The geographic and geomorphic setting of the Colorado River in Grand Canyon creates multiple opportunities for nonnative species introductions that may be successful across varied environmental gradients. The Colorado River below Glen Canyon Dam extends $472 \mathrm{~km}$ downstream to the beginning of Lake Mead (fig. 1), passing through Glen Canyon National Recreation Area and 
Grand Canyon National Park. From Glen Canyon Dam to Lake Mead, the river drops in elevation 580 $\mathrm{m}$. Within the river corridor, there are 600 tributaries that connect to the mainstem, but few of these tributaries have perennial flows (Griffiths and others, 1996). These tributaries are potential sources for plant introductions that may occur through dispersal of seeds by flash floods associated with summer monsoon rains, fall storms, or spring runoff. The geographic location of the river and its course also intersects three floristic provinces: the Colorado Plateau, the Mojave Desert, and the Sonoran Desert (Brown, 1982). These floristic provinces span a range of environmental conditions and are all sources for introduced plant species.

\section{High-Flow Experiment}

Introducing artificial floods into regulated systems began in the 1990s and continues today (Webb and others, 1999; Patten and Stevens, 2001; Robinson and Uehlinger, 2003; Rood and others, 2003; U.S. Geological Survey, 2007). A 472-km section of the Colorado River stretching from below Glen Canyon Dam to the mouth of Lake Mead, including Grand Canyon National Park (fig. 1), has been the subject of study about the effects of flooding in a regulated system. A primary purpose of reintroducing flooding to the Colorado River below Glen Canyon Dam was to evaluate the ability of HFEs to conserve sediment by moving sediments stored in eddies to higher areas above annual operating hydrographs (Webb and others, 1999). Habitat rejuvenation and litter removal was also anticipated in association with sediment reworking and conservation (Parnell and others, 1999). Although shoreline habitat rejuvenation associated with aquatic species such as the endangered humpback chub was a primary focus associated with sediment reworking, it was also recognized that the flood disturbance could be an organizing force in riparian communities (Webb and others, 1999). Resource managers hypothesized that a discharge greater than powerplant capacity $\left(877 \mathrm{~m}^{3} / \mathrm{s}\right)$ would remove both living and dead vegetation that had accumulated within the riparian zone since the late 1980s and "reset" riparian vegetation dynamics (Webb and others, 1999). The presence of nonnative plants in the riparian community and the susceptibility of the system to nonnative introductions raised questions as to how periodic flooding would affect nonnative species establishment, particularly tamarisk, in the riparian zone.

High levels of seasonal precipitation in October 2006 and August and September 2007 caused sediment inputs to the mainstem from the Paria River, a tributary to the Colorado River, to reach an estimated 2,500,000 metric tons ( $\pm 500,000$ metric tons) of sand in 2007 (U.S. Geological Survey, 2007). These sediment inputs were the equivalent of a once in a decade input event, and the sediment supplied was considered sufficient to implement a HFE. A total of three HFEs have been undertaken to evaluate the ability of high flows to conserve sediment and rebuild sediment deposits following extended periods of erosion. The 2008 experiment was approximately half the magnitude of the historical annual flood discharge (Topping and others, 2003). The duration of the 2008 HFE was 60 hours and of a short duration compared to the historical annual spring runoff hydrograph, which spanned the months of March through June (Topping and others, 2003). Nonetheless, this manmade disturbance provided the context for evaluating how timing and frequency of a high flow affects the location and extent of establishment of nonnative plants, particularly tamarisk, along the river corridor. 


\section{Methods and Analysis}

\section{Methods}

The study was carried out along $425 \mathrm{~km}$ of the Colorado River between Lees Ferry and Diamond Creek, Ariz. (fig. 1). From March 5 to 9, 2008, the third Glen Canyon Dam HFE was conducted, producing a high, sustained flow of $1,161 \mathrm{~m}^{3} / \mathrm{s}$ for 60 hours. A total of 80 sites were sampled immediately after the HFE (March 25-April, 13, 2008) and the same sites were resampled 6 months later (September 20-October 3, 2008); however, 9 of these 80 sites were missed on the September trip. The sampled sites included sites that were used for camping and more vegetated sites that are not used generally for camping. The camping sites, which are used by whitewater rafters and hikers, are monitored for area and volume changes as part of the Grand Canyon Monitoring and Research Center's program of long-term monitoring of sandbars and mass balance of sand budgets (Kaplinski and others, 2005). The vegetated sites were previously surveyed for community identification and "ground truthing" associated with vegetation mapping (Ralston and others, 2008). The sites did not differ in species richness or composition (U.S. Geological Survey, unpub. data, 2008).

\section{Comparing Richness and Cover Among Vegetation Zones}

The four post-dam vegetation zones (HRZ, LRZ, MRZ, and URZ) were compared in this study for total richness, nonnative species richness, and percent cover to address questions about frequency of disturbance and susceptibility to nonnative species invasions. Cover and richness were measured at each study site by establishing a $50-\mathrm{m}^{2}$ plot in each of the four vegetation zones. The locations of the hydrologic zones along the channel banks were determined by stage elevation relationships for campsites (Hazel and others, 2006). Because of the variable slopes associated with local geology along the river corridor (Schmidt and Graf, 1990), plots within the four vegetation zones were generally rectangular in shape, and the longer edge of the plot ran parallel to the river. Plot size was selected to ensure efficient sampling, to provide better representation of cover of shrubs and trees located in the riparian vegetation zones farther from the edge of the river, and to accommodate the heterogeneous nature of riparian communities (Kenkel and Podani, 1991; Elzinga and others, 2001). The linear shapes of the plots reflect the hydrologic component of the shoreline with vegetation composition being more consistent linear to the water surface than perpendicular. For each plot, all species present were identified and the percent cover was estimated for each plant species by assigning a categorical scale of cover ( $<1$ percent (trace), 1-5 percent, 5-25 percent, 25-50 percent, 50-75 percent, 75-95 percent, $>95$ percent; Braun-Blanquet, 1965), recognizing that $1 \mathrm{~m}^{2}=2$ percent cover within a plot. The appendix provides a list of the species found during this study. Plants were identified as native or nonnative using the national PLANTS Database (U.S. Department of Agriculture, 2010). When plants could not be identified to a species, identification was assigned at the genus level. For analytical purposes, when confusion arose among several species of a single genus (for example, Juncus species), these taxa were lumped into a single genus category. For cover analysis, plants listed with just a trace $(<1$ percent $)$ were excluded.

\section{Sediment Sampling for Percent Organic Matter, Total Carbon, and Total Nitrogen}

As a supplement to the richness and percent cover data, sediment samples were collected to determine if percent total carbon, percent total nitrogen, and percent total organic matter varied among the four hydrologic zones. Soil samples were taken only during the first sampling trip. For 
each vegetation zone, three random samples were collected to a depth of $15 \mathrm{~cm}$ and mixed in a bucket to create an integrated sample. A 200-ml sample was taken from this integrated sample for later analysis. The four vegetation zones were sampled at 40 study sites (20 campsites and 20 vegetated noncampites) for a total of 160 samples (four samples per site). Soil samples were processed at Utah State University's Analytical Soil Labs, where standard procedures (using a loss of ignition analyzer) were used to quantify percent total carbon and percent total nitrogen and percent total organic matter (http://www.usual.usu.edu/about/quality/index.html).

\section{Analyses}

Data associated with species richness, percent total cover, and the components associated with the sediment samples were evaluated for normality. If data were found not to be normally distributed, transformations were applied. If the data transformations failed tests for normality, then analyses were conducted using nonparametric statistics. All data were analyzed using nonparametric statistics. To compare differences in richness and percent vegetative cover among riparian vetetation zones, a nonparametric Kruskal-Wallis one-way analysis of variance by ranks (ANOVA $\mathrm{KW}_{\mathrm{W}}$ ) was used. To understand if there were differences in nonnative cover among zones, mean percent nonnative cover among riparian zones was compared using an $\mathrm{ANOVA}_{\mathrm{KW}}$. Comparisons of percent cover between sample periods within vegetation zones were made using a Mann-Whitney U test. This test allows for comparison between uneven sample sizes present in this dataset.

To understand how vegetation changes between sample periods affected overall percent cover within zones, taxa were segregated into four categories (that is, shrubs/trees; shrubs $<1 \mathrm{~m}$; forbs; and grasses, sedges, and rushes) and a Mann-Whitney U test was applied to each category. Statistical software that was used for this analysis was Systat Software, Inc., SigmaPlot ${ }^{\circledR} 11$ (2008).

\section{Results}

The 2008 HFE resulted in deposition of sediment on sandbars within debris-fan eddy complexes and along channel margins. Vegetation in the HRZ was predominately scoured, although some burial was also evident, particularly within return channel environments. Vegetation dominated by shrubs and bunch grasses in higher vegetation zones was partially buried. The ground surfaces at surface elevations up to $1,161 \mathrm{~m}^{3} / \mathrm{s}$ were devoid of litter, but organic matter (for example, woody debris, Cladophora) was stratified within the sand deposits and suspended in the woody vegetation.

\section{Total Richness Among Vegetation Zones}

Mean total richness in all riparian zones was low in April and September (fig. 4) and not significantly different among zones. Median richness varied between two and three species among zones in April $\left(\mathrm{H}_{(78,3)}=1.588\right.$, $\mathrm{p}_{\mathrm{kw}}=0.662$ 1.068; fig. 4), whereas median richness among zones in September was three species $\left(\mathrm{H}_{(70,3)}=1.068\right.$, $\mathrm{p}_{\mathrm{kw}}=0.785$; fig. 4). Richness within riparian zones did not change significantly between sample periods. 


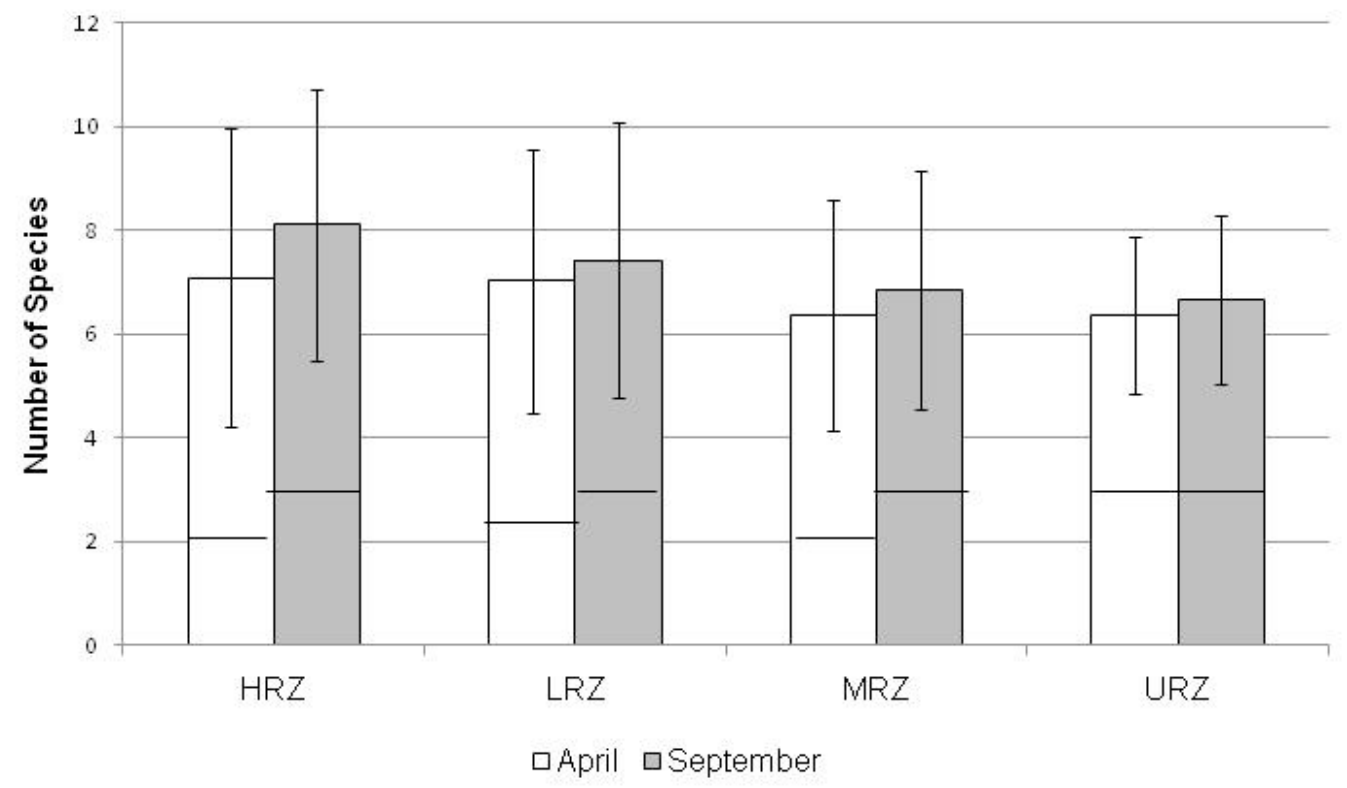

Figure 4. Bar graph showing mean total species richness in riparian vegetation zones (HRZ=Hydro Riparian Zone, LRZ=Lower Riparian Zone, MRZ=Middle Riparian Zone, and URZ=Upper Riparian Zone) in Grand Canyon, Ariz., in April and September $2008(p \geq 0.05)$. Lines within bars are median richness values within each zone. Error bars represent 95-percent confidence intervals of the mean.

\section{Nonnative Richness Among Riparian Vegetation Zones}

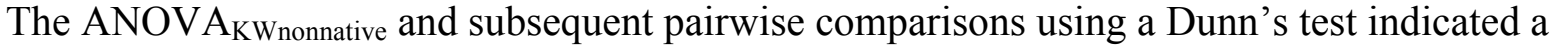
greater nonnative richness in the URZ compared with the other vegetation zones that was statistically significant in April $\left(\mathrm{H}_{(78,3)}=22.29 \mathrm{p}_{\mathrm{kw}} \leq 0.001\right.$; fig. 5) and September $\left(\mathrm{H}_{(70,3)}=9.59, \mathrm{p}_{\mathrm{kw}} \leq 0.02\right.$; fig. 5). Nonnative richness in the URZ was greater compared to other zones in April, whereas in September richness in the URZ was only significantly greater than the LRZ. The higher richness value observed in the URZ was associated with winter and spring annual grasses and forbs, which include Bromus species and Russian thistle (Salsola tragus). 


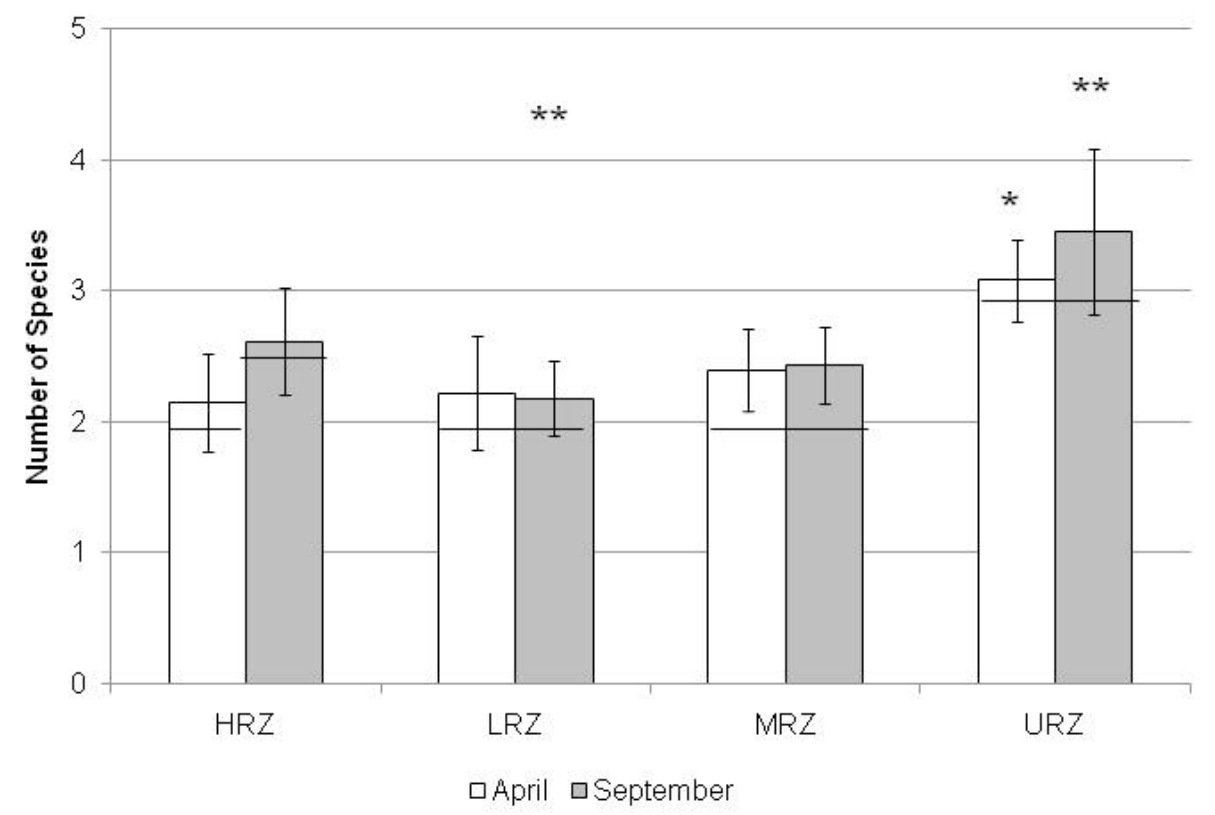

Figure 5. Bar graph showing mean nonnative species richness in riparian vegetation zones (HRZ=Hydro Riparian Zone, LRZ=Lower Riparian Zone, MRZ=Middle Riparian Zone, and URZ=Upper Riparian Zone) in Grand Canyon, Ariz., in April and September 2008. Lines within bars indicate median values of percent cover. Single asterisk (*) indicates that nonnative richness was statistically different in the URZ compared with the other zones in April. Two asterisks ${ }^{(*)}$ indicate that nonnative richness was statistically different in LRZ and URZ compared with the other zones in September. Error bars represent 95-percent confidence intervals of the mean.

\section{Percent Vegetated Cover Among Riparian Vegetation Zones and Between Sample Periods}

Percent vegetated cover among riparian zones was significantly different in April 2008 (ANOVA $\mathrm{KW}_{\text {cover }} \mathrm{H}_{(78,3)}=109.73, \mathrm{p}_{\mathrm{kw}}<0.001$ ). Pairwise multiple comparisons (Tukey test) identified significant differences in cover among the HRZ and MRZ and URZ and among the LRZ and MRZ and URZ in April (fig. 6A). Median cover values for the MRZ and URZ were 25.5 and 27.0 percent, respectively, whereas cover values for the HRZ and LRZ were 3.0 and 6.0 percent, respectively. By September, median cover values had increased among all riparian vegetation zones and significant differences in cover among zones persisted $\left(\right.$ ANOVA $\left.\mathrm{KWcover} \mathrm{H}_{(70,3)}=54.5, \mathrm{p}_{\mathrm{kw}}<0.001\right)$. A Tukey test determined that the percent cover was significantly different among riparian zones except between the URZ and the MRZ (fig. $6 B$ ). 
$A$

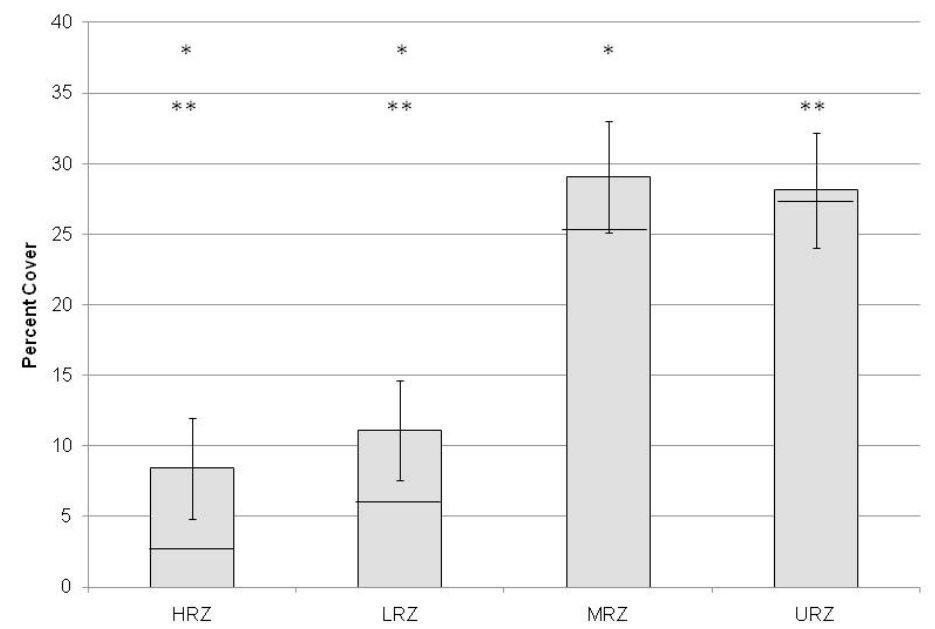

$B$

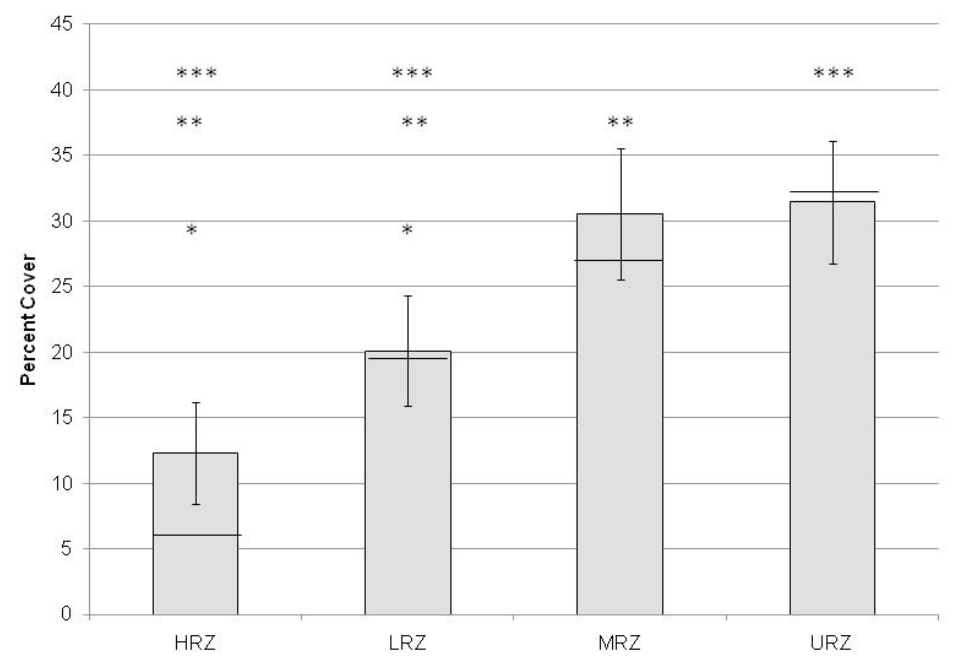

Figure 6. Bar graphs showing mean percent vegetative cover in riparian vegetation zones (HRZ=Hydro Riparian Zone, LRZ=Lower Riparian Zone, MRZ=Middle Riparian Zone, and URZ=Upper Riparian Zone) in Grand Canyon, Ariz., in $(A)$ April and $(B)$ September 2008. Lines within bars indicate median values of percent cover. For April $(A)$ a single asterisk $\left(^{*}\right)$ indicates that the percent cover for the MRZ was statistically significantly greater than the LRZ and HRZ. Two asterisks ${ }^{* *}{ }^{*}$ indicate that the URZ was statistically significantly greater than the LRZ and HRZ in April. By September $(B)$, mean percent cover in all zones increased, and the percent cover in the LRZ was statistically significantly greater compared to the HRZ $\left(^{*}\right)$. The mean cover in the MRZ was statistically significantly greater than the LRZ and HRZ $\left({ }^{* *}\right)$, and the URZ was still statistically significantly greater than the LRZ and HRZ $\left.{ }^{* * *}\right)$. Error bars represent 95-percent confidence intervals of the mean. 


\section{Percent Cover Change Within Riparian Vegetation Zones}

Percent cover between sample periods increased significantly in the HRZ $\left(\mathrm{U}_{\mathrm{HRZ}}=2206\right.$, $\mathrm{p}=0.039$; fig. 7) and LRZ $\left(\mathrm{U}_{\mathrm{LRZ}}=1680, \mathrm{p}<0.001\right.$; fig. 7) between April and September 2008. Within the HRZ and LRZ, only the shrub/trees category was significantly different $\left(U_{H R Z}=2281.0, p=0.02\right.$, Mann-Whitney $\mathrm{U}_{\mathrm{LRZ}}=1378.0, \mathrm{p} \leq 0.001$ ) between April and September (fig. 8). Further comparisons (Mann-Whitney U test) of individual taxa within the shrub/tree category identified a significant decrease in cover for Baccharis spp. in the HRZ in September compared with April ( $U_{\text {Baccharis }}$ $=2398.0, \mathrm{P}=0.047$ ), but this obviously did not explain the increase in cover observed in the HRZ. The increased cover observed in the HRZ could not be explained by the contribution of a single vegetation category. Instead, the cumulative increased cover in the grasses and forbs category accounted for the increased percent cover observed in HRZ (fig. 8). Within the LRZ, Baccharis spp., Salix exigua, and Tamarix sp. significantly increased in percent cover between April and September $\left(\mathrm{U}_{\text {Baccharis }}=1971\right.$, $\mathrm{p}=0.002, \mathrm{U}_{\text {Salix }}=1922, \mathrm{p} \leq 0.001, \mathrm{U}_{\text {Tamarisk }}=2295, \mathrm{p}=0.019$; fig. 9). Mean cover of Tamarix $\mathrm{sp}$.

increased by 260 percent from 0.5 to 1.8 percent cover, Salix exigua increased in percent cover by 425 percent from 0.5 to 4.2 percent, and Baccharis spp. increased 84 percent from 2.78 to 5.12 percent.

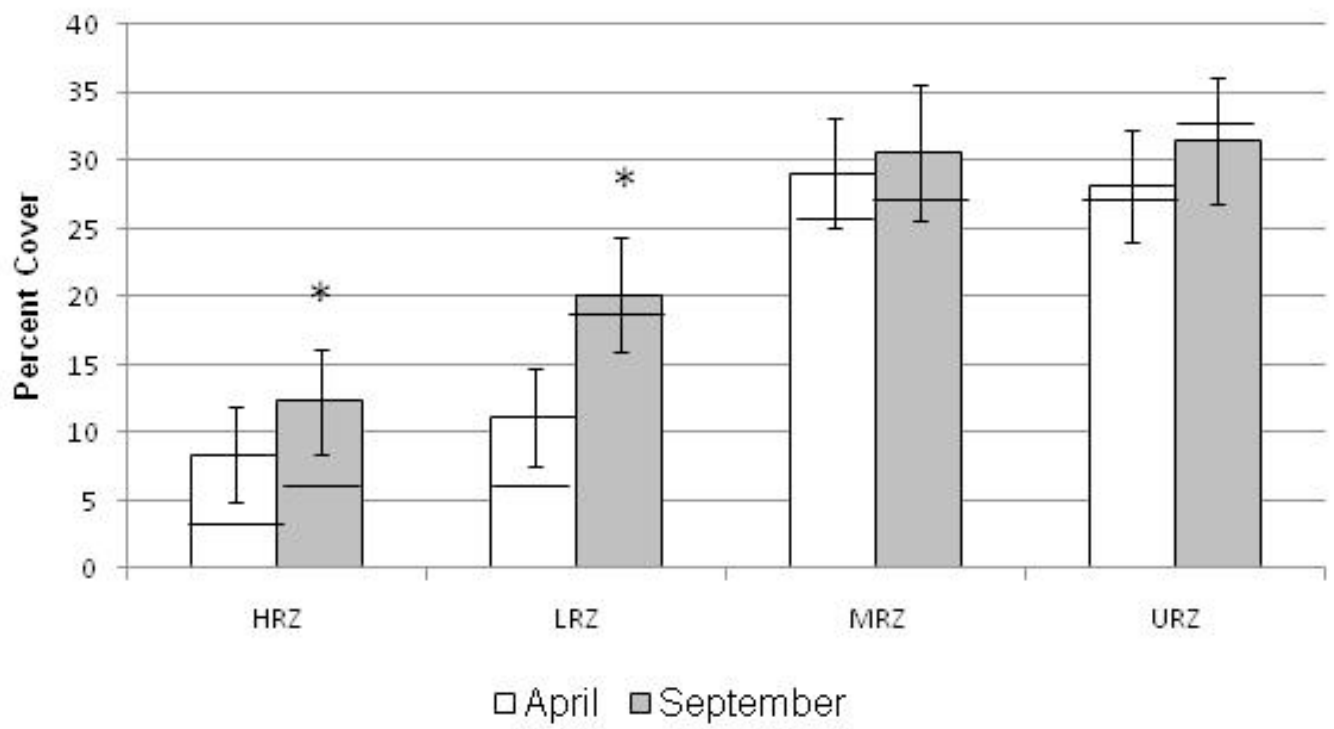

Figure 7. Bar graph showing mean percent vegetative cover in riparian vegetation zones (HRZ=Hydro Riparian Zone, LRZ=Lower Riparian Zone) in Grand Canyon, Ariz., in April and September 2008. Lines within bars indicate median values. Asterisk $\left(^{*}\right)$ indicates that mean percent cover increased statistically significantly ( $p \leq 0.05$ ) in the HRZ and LRZ between sample periods. Error bars represent 95-percent confidence intervals of the mean. 


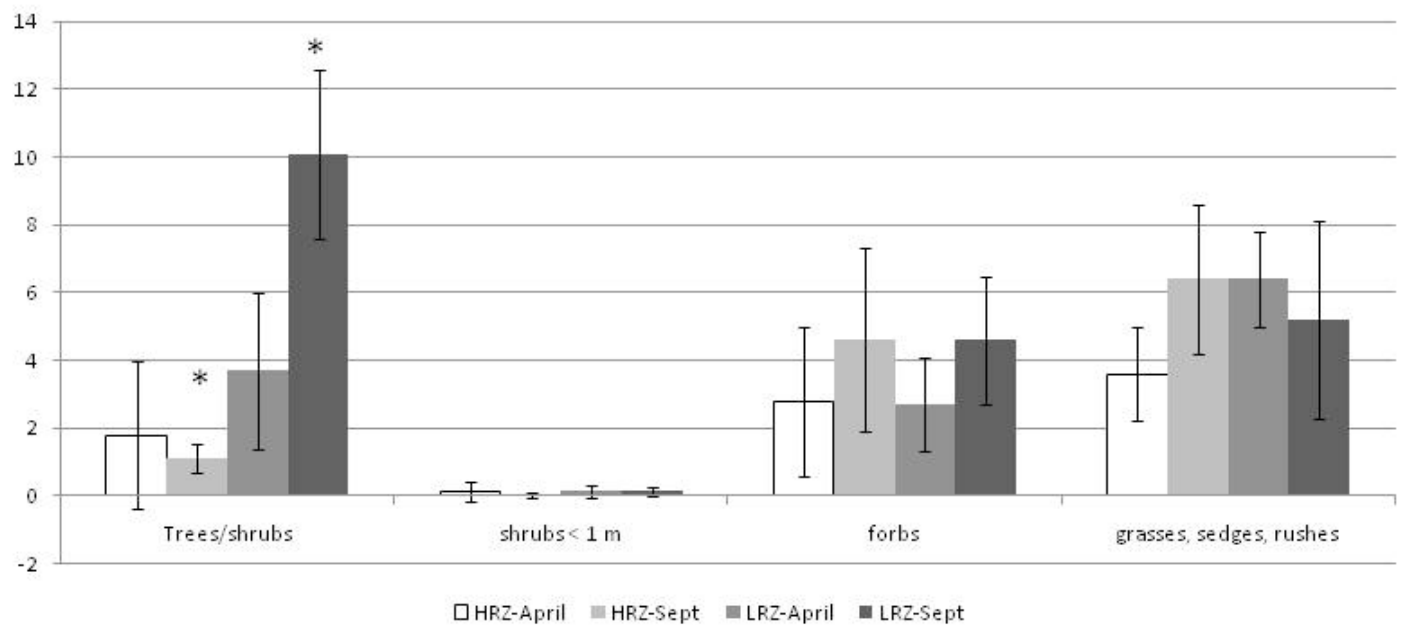

Figure 8. Bar graph showing mean percent vegetative cover of plant categories contributing to significant cover changes within the Hydro Riparian Zone (HRZ) and the Lower Riparian Zone (LRZ) in Grand Canyon, Ariz., in April and September 2008. Asterisk ( $\left.{ }^{*}\right)$ indicates that mean percent cover of the tree/shrub category decreased statistically significantly $(p<0.05)$ in the HRZ and increased statistically significantly $(p<0.05)$ in the LRZ between sample periods. Error bars represent 95-percent confidence intervals of the mean.

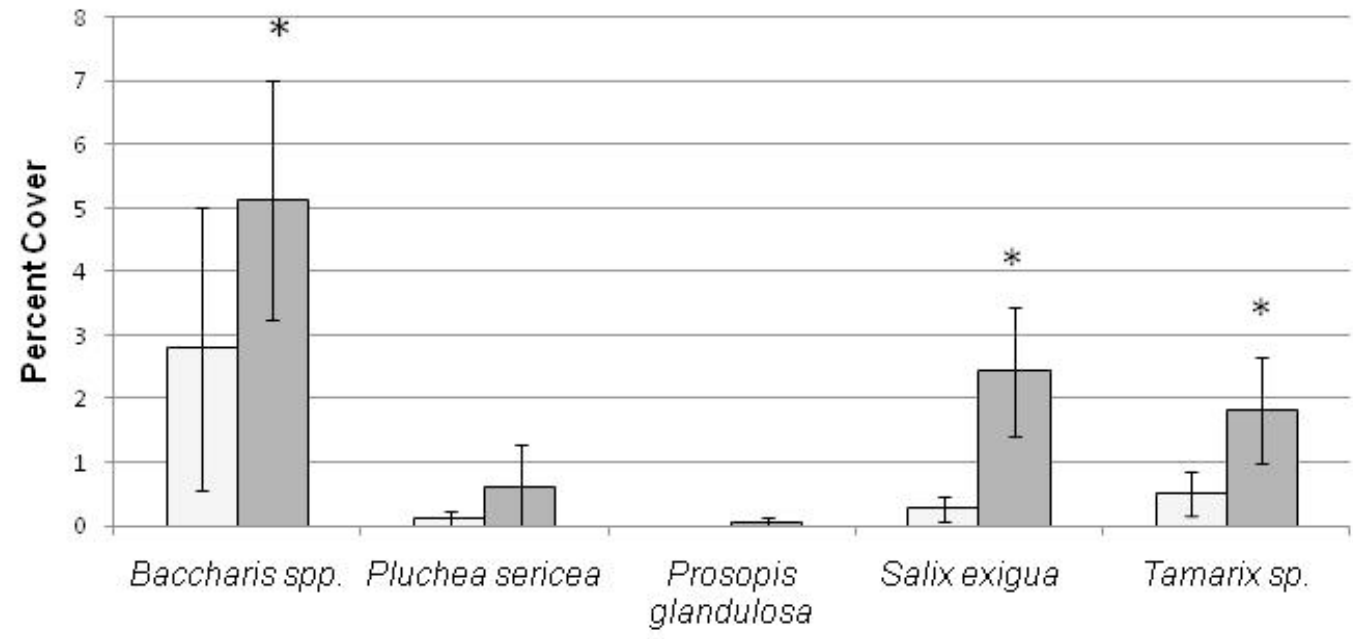

$\square$ April $\square$ September

Figure 9. Mean percent vegetative cover of five woody riparian species in the Lower Riparian Zone in Grand Canyon, Ariz., in April and September 2008. Asterisk ( $\left.{ }^{*}\right)$ indicates that mean percent cover of Baccharis spp. (Baccharis emoryi and $B$. salicifolia), Salix exigua, and Tamarix sp. increased statistically significantly $(p<0.05)$ between sampling periods. Error bars represent 95-percent confidence intervals of the mean. 


\section{Nonnative Cover Between Sample Periods and Among Riparian Vegetation Zones}

Although mean percent cover of nonnative species increased in all riparian vegetation zones between sample periods, except in the HRZ (fig. 10), the changes in cover were not statistically significant $(\mathrm{p} \geq 0.05)$. Percent cover of nonnative species was not different statistically in either April or September 2008 for individual vegetation zones or among the four zones ( $\mathrm{p} \geq 0.05$; fig. 10).

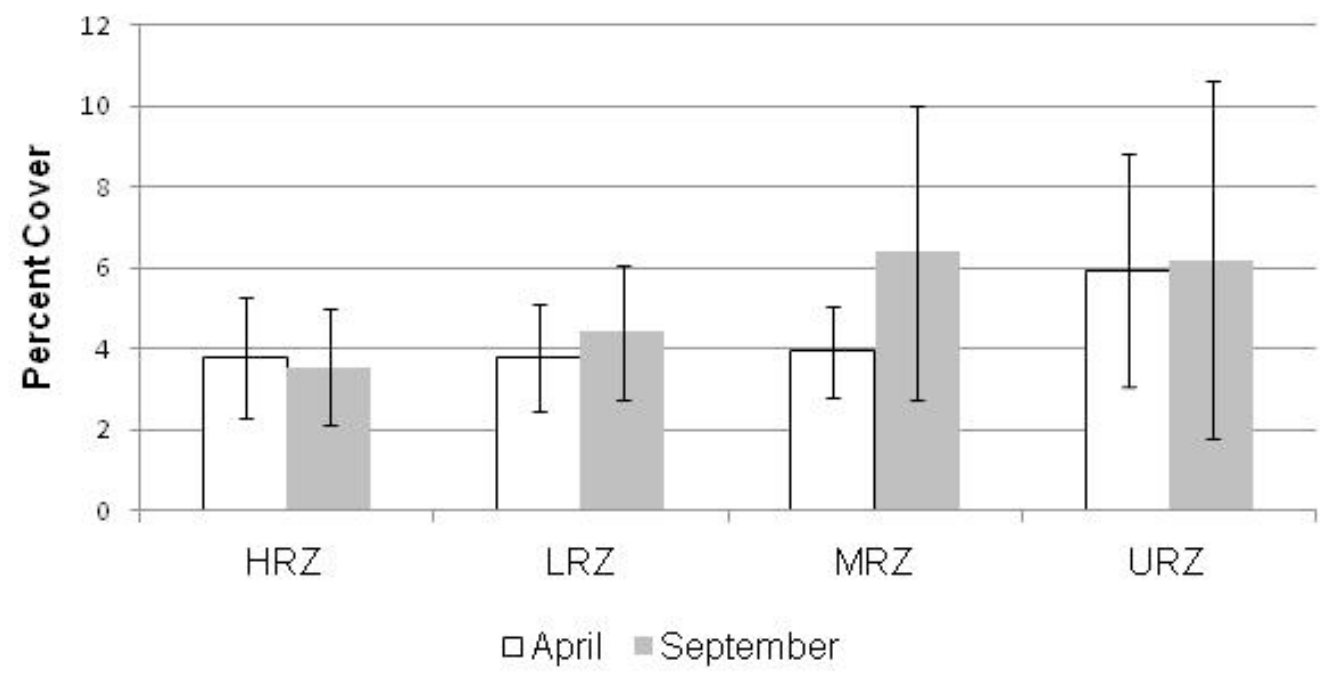

Figure 10. Bar graph showing mean percent vegetative cover of nonnative plants in riparian vegetation zones (HRZ=Hydro Riparian Zone, LRZ=Lower Riparian Zone, MRZ=Middle Riparian Zone, and URZ=Upper Riparian Zone) in Grand Canyon, Ariz., in April and September in 2008. Error bars represent 95-percent confidence intervals of the mean.

\section{Sediment Samples Among Zones}

The ANOVA $\mathrm{KW}_{\mathrm{K} \text { sediment }}$ indicated no difference among zones for either percent total carbon or percent organic matter $\left(\mathrm{H}_{\text {Total }} \mathrm{C}_{(42,3)}=2.145, \mathrm{p}_{\mathrm{kw}}=0.543 ; \mathrm{H}_{\mathrm{OM}(42,3)}=1.25, \mathrm{p}_{\mathrm{kw}}=0.741\right)$. Total nitrogen values were below detection levels.

\section{Changes in Cover of Taxa of Special Interest}

There were more species observed in April than in September 2008 (154 species versus 126 species; appendix). The differences between these sample periods reflect the presence of winter and spring annuals in the April census period. Woody riparian species were the most frequently encountered species and accounted for the greatest amount of cover in all riparian zones followed by grasses and forbs (fig. 11). Among wetland taxa, Phragmites and Schoenoplectus showed the greatest change in percent cover between sample periods, although only cover change in Schoenoplectus was statistically significant $\left(\mathrm{U}_{\text {Schoenoplectus }}=4953, \mathrm{p}=0.01\right.$; fig. 12). Mean cover for Phragmites increased 200 percent from 0.5 to 1.5 percent, and Schoenoplectus increased 800 percent from 0.07 to 0.75 percent cover. 
The number of nonnative species differed between sampling periods with more nonnatives observed in April than in September (43 species versus 36 species). The presence of winter and spring annuals (for example, Bromus tectorum, B. rubens, Erodium cicutarium) in April accounts for the differences in species encountered between sample periods. As noted above, the LRZ was the only vegetation zone in which tamarisk cover increased significantly (fig. 9).

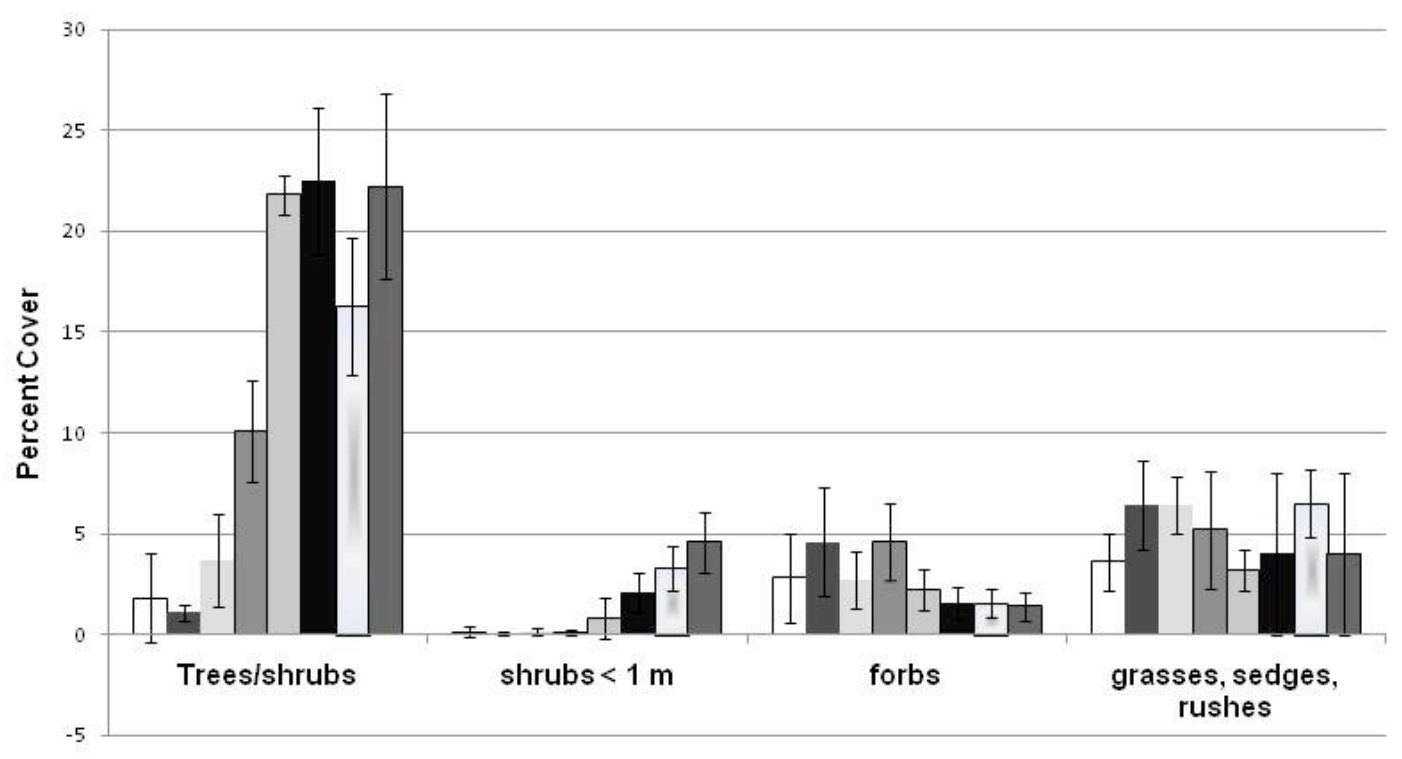

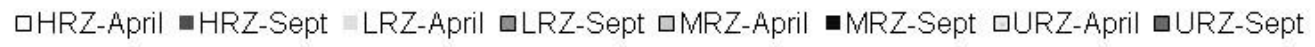

Figure 11. Mean percent cover of vegetation categories (trees/shrubs, shrubs $<1 \mathrm{~m}$ tall, forbs, and grasses) in riparian vegetation zones (Hydro Riparian Zone=HRZ, Lower Riparian Zone=LRZ, Middle Riparian Zone= MRZ, and Upper Riparian Zone=URZ) in Grand Canyon, Ariz., in April and September 2008. April and September cover values for each riparian zone are paired within each vegetation category. Error bars represent 95-percent confidence intervals of the mean. 


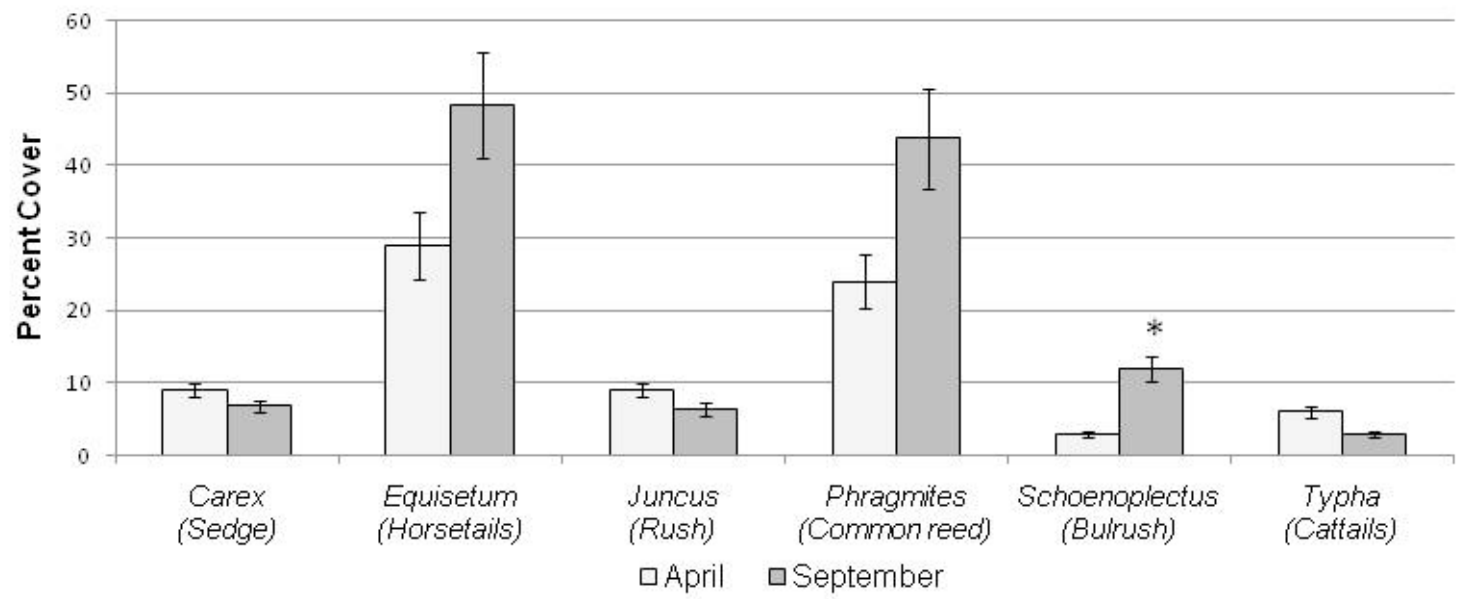

Figure 12. Bar graph of five wetland taxa in April and September 2008 for all riparian vegetation zones (HRZ=Hydro Riparian Zone, LRZ=Lower Riparian Zone, MRZ=Middle Riparian Zone, and URZ=Upper Riparian Zone) in Grand Canyon, Ariz. Asterisk ( $\left.{ }^{*}\right)$ indicate statistically significant differences $(p<0.05)$ in percent cover between sampling periods. Error bars represent standard error of the mean.

\section{Discussion}

\section{Nonnative Plant Establishment}

Among the riparian vegetation zones, nonnative richness was greatest in the URZ in both April and September 2008 (fig. 5). The higher richness value observed in the URZ was associated with winter and spring annual grasses and forbs, which include Bromus species, Russian thistle, stink grass (Eragrostis cilianensis), Mediterranean grass (Schismus barbatus), and filaree (Erodium cicutarium). The HFE may have provided a brief dousing to seeds in the URZ that initiated germination among some of the annual species. The presence of some species, like Russian thistle, became more pronounced by September, following their usual seasonal pattern of growth. Because the seeds of these species also depend on winter and spring rains for germination, it is difficult to attribute changes in richness observed in 2008 to the HFE. Comparing trends in cover and richness of the nonnative annuals from long-term monitoring data with those cover values observed in association with an HFE would be a better approach.

Total vegetation cover varied among riparian zones, and zones with lower frequency of disturbance (that is, URZ and MRZ) were associated with higher cover values. Differences in cover among vegetation zones became more pronounced through the growing season (figs. 6, 7, 11). In contrast to the pattern observed with total cover, the percent cover of nonnative plants among riparian zones was similar (fig. 10) and did not change between sampling periods. The similarity in cover of nonnative species among riparian vegetation zones is likely attributable to the presence of tamarisk, which was the dominant nonnative in each zone. Among the zones, only the LRZ had a significant increase in tamarisk cover (fig. 9). Tamarisk cover in zones other than the LRZ increased but not significantly, suggesting the changes in cover were likely associated with seasonal growth rather than recruitment of seedlings. In contrast, the increased cover in the LRZ was likely associated with a combination of seasonal growth of existing tamarisk and tamarisk seedling establishment. The change 
in tamarisk cover in the LRZ was smaller compared with either Salix exigua or Baccharis spp. (fig. 9) and suggests that seedling establishment following the HFE was limited.

The pattern observed in the URZ of higher nonnative richness and greater cover compared with other zones was likely because of the contribution of nonnative spring annuals, including brome grasses and annual mustards, a natural seasonal occurrence. The results associated with tamarisk seedling establishment most prominently occurring in the LRZ support the pattern that areas of low cover may be more susceptible to nonnative species invasions following a disturbance. Historical patterns of nonnative plant invasion along the river corridor are coincident with expansion into areas of low cover (Turner and Karpiscak, 1980; Stevens and Waring, 1986).

Percent cover and disturbance frequency are factors that collectively may make the LRZ more susceptible to nonnative plant invasions compared to other riparian vegetation zones. If percent cover is considered first, percent total cover in April was similar in both the LRZ and HRZ (fig. 6). The similarity in percent cover for the LRZ and HRZ would suggest that if cover were the only factor affecting susceptibility to tamarisk invasion, then both zones would be equally susceptible. Over time, cover in both zones increased significantly (fig. 8), but the type of vegetation that increased differed between the two zones. Woody riparian vegetation increased significantly in the LRZ, while it decreased significantly in the HRZ (fig. 8). The daily fluctuations that occur in the HRZ have been shown to result in less hospitable habitats for woody riparian plant survival (Stevens and others, 1995; Gladwin and Roelle, 1998; Porter, 2002). Instead, cover of forbs, grasses, sedges, and rushes increased in the HRZ, and Stevens and others (1995) identified these taxa as more tolerant of daily inundation. The LRZ, which had reduced cover initially following the HFE compared with either the MRZ or URZ and exhibited lower disturbance following the HFE compared to the HRZ, was a more susceptible to tamarisk seedling establishment than any of the other riparian zones. The significant change in cover among other woody shrubs in the LRZ (fig. 9) suggests that this zone is one in which woody riparian plant can occupy and expand quickly following a disturbance compared with either the MRZ or URZ, possibly the result of more water availability.

\section{Timing of High-Flow Experiments}

Tamarisk was the only nonnative plant for which changes in cover and seedling establishment can be attributed to the HFE. Other nonnative species that increased in cover between spring and fall were winter and spring annuals, like Russian thistle and cocklebur, but these increases were likely not significantly more than in a typical year. The absence of a continuous long-term monitoring dataset precludes knowing this finding with certainty. There was evidence of tamarisk seedling establishment following the $2008 \mathrm{HFE}$, however, the extent of tamarisk establishment was not as great as was reported following the steady flow experiment conducted in 2000 (Porter, 2002). In 2008, tamarisk cover in the LRZ averaged $<2$ percent, which included tamarisk seedlings and older established individuals.

The timing of the 2008 March HFE likely contributed to reduced opportunities for tamarisk seedling establishment. Because tamarisk produces flowers and seeds from April through September, the March disturbance provided an opportunity for other species (for example, spring annuals and clonal perennials) to establish in available areas, thus reducing site availability for tamarisk seedlings. Kearsley and Ayers (1999) document similar low tamarisk seedling establishment following the March 1996 HFE, which was followed by a month of reduced discharges that desiccated sandbars.

In contrast to HFEs conducted in March, the Low Summer Steady Flow experiment that took place in the spring and summer of 2000 (Valdez and others, 2000) was optimal for tamarisk establishment. In the summer of 2000, tamarisk seedlings were observed in high densities (626 
stems $/ \mathrm{m}^{2}$ in August 2000) following a period of extended high flows in the spring of 2000 and a shortduration high flow that occurred in May. In this case, a 4-day disturbance event in the form of a habitat-maintenance flow of $877 \mathrm{~m}^{3} / \mathrm{s}$ magnitude was initiated in May followed by reduced discharge to $226 \mathrm{~m}^{3} / \mathrm{s}$ for 3 months from June through August. Exposing bare beach areas in June coincided with a peak time for tamarisk seed production and seedling establishment (Porter, 2002). If a goal of an HFE is to reduce the likelihood of tamarisk seedling establishment, the results from 2008 suggest that undertaking HFEs in March is favorable.

All seedling establishment above the LRZ was also likely reduced in 2008 . The continued coarsening of sediment in the river corridor (Topping and others, 1999, 2000; Schmidt and others, 2004) may contribute to limited seedling establishment by increasing sediment porosity and decreasing absorptive properties of the sediment (Stevens, 1989a). Additionally, Kearsley (2006) found that plants in the study area occupying areas above $877 \mathrm{~m}^{3} / \mathrm{s}$ were more affected by local precipitation than by annual dam operations.

\section{Wetland Species of Interest}

With respect to six wetland taxa (Carex, Equisetum, Juncus, Phragmites, Schoenoplectus, and Typha), the taxa responded differently. Most taxa, except Typha, showed an increase in cover over the season, but only Schoenoplectus increased significantly in cover (fig. 12). Typha may not have changed in cover as the result of organic litter removal during the successive HFEs and the overall coarsening of the sandbar deposits since 1996 (Topping and others, 1999, 2000; Schmidt and others, 2004). In other aquatic systems where cattails are present, there is a positive correlation between Typha (Typha glauca) and the biomass accumulation of organic litter, whereas removal of organic litter favors Phragmites (Farrer and Goldberg, 2009; Tuchman and others, 2009). The series of three HFEs that have occurred between 1996 and 2008 may have removed organic litter and affected cattail presence along the Colorado River below Glen Canyon Dam. Since 1996, the cumulative coarsening of sediment deposits along shorelines (Topping and others, 1999, 2000; Schmidt and others, 2004) may also affect cattails by decreasing anaerobic soil conditions (Amsberry and others, 2000) and increasing sediment grain size resulting in lower moisture holding capacity. Changes in the quantity of organic litter and sediment grain size following successive HFEs may limit wetland development and favor Phragmites growth over Tyhpa (Stevens, 1989a) and increase cover of Equisetum sp. (Stevens and others, 1995). This pattern may be perpetuated in subsequent growing seasons depending on HFE frequency.

\section{Comparisons with Previous Floods}

Since the Record of Decision in 1996 (U.S. Department of the Interior, 1996), there have been three HFE events in 1996, 2004, and 2008 (Webb and others, 1999; Topping and others, 2006); however, accompanying vegetation studies only occurred in 1996 and 2008. It was anticipated in 1996 that vegetation would be scoured as a result of the $1,274 \mathrm{~m}^{3} / \mathrm{s} 7$-day high flow, and the reintroduced flood disturbance would work as a community organizing variable (Schmidt and others, 1999). Kearsley and Ayers (1999) reported that the sites they studied following the 1996 HFE experienced more sediment deposition than scour; these observations were corroborated by Hazel and others (1999) in a study measuring sandbar areas and volumes. The findings of Kearsley and Ayers (1999) indicate that riparian and wetland taxa adapted to burial (for example, Baccharis sp., Salix exigua, Phragmites australis, Typha latifolia) quickly recovered to at least areal cover values observed before the 1996 disturbance. The authors also reported a general loss of seed sources and seed diversity within sandbars following the 1996 HFE. Kearsley and Ayers (1999) did not speculate 
on whether the $1996 \mathrm{HFE}$ acted as a community organizational force on the riparian vegetation; instead, they concluded that the 1996 HFE failed to achieve the goal of vegetation removal and community regeneration. Kearsley and Ayers (1999) did not address timing as an important variable in limiting post-flood tamarisk germination.

The evaluation of the success or failure of HFEs to reorganize riparian vegetation is merited not only because two additional HFEs have occurred since 1996, but also because the trajectory of riparian plant communities can vary following a flood disturbance. For example, since 1996, changes resulting from successive HFEs (for example, the coarsening of sediment and the partial burial of vegetation) may be acting as forcing variables that are shifting the composition of the riparian community to one dominated by clonal woody riparian species in the LRZ, MRZ, and URZ (fig. 11) and clonal wetland species in the HRZ. A riparian community response favoring clonal species was a hypothesis promoted by Stevens (1989a) before changes in Glen Canyon Dam operations took place in the 1990s (Department of the Interior, 1996). The 1996 and 2008 HFEs buried vegetation instead of scouring it. In both years the magnitude and duration of the HFE was insufficient to remove vegetation, except in the HRZ, and clonal species recovered more quickly than nonclonal species (for example, Salix exigua versus Tamarix sp.). The recovery of plants adapted to burial is evident in 2008 in the LRZ where Baccharis spp. and Salix exigua cover increased significantly and contributed to the increased woody vegetation cover observed in September (figs. 8, 9, and 11).

In contrast, the uncontrolled floods observed in the mid-1980s (discharges $>877 \mathrm{~m}^{3} / \mathrm{s}$ ) were prolonged for months resulting in vegetation scour rather than burial in areas below flood stage (Stevens and Waring, 1986). Following these prolonged uncontrolled floods, seedlings, particularly tamarisk seedlings, dominated newly exposed sediment deposits (Stevens and Waring, 1986). More recently, Porter (2002) also recorded high densities of tamarisk seedlings following a spring hydrograph of prolonged high flows that resulted in scour and exposure of open areas. Tamarisk's ability to become quickly established in open areas is supported elsewhere in the Southwestern United States (Sher and others, 2002; Sher and Marshall, 2003).

It is likely that the 1996 and 2008 HFEs resulted in limited tamarisk seedling establishment because the experiments were timed to take place before tamarisk seeds are produced and vegetation was buried instead of removed. The increased frequency of HFEs since 1996 has resulted in reduced litter accumulation, possibly reduced seed bank diversity and storage, and coarsening of substrates (Topping and others, 1999, 2000; Schmidt and others, 2004). These results combine to influence riparian and wetland species composition by supporting clonal species over seed-based species and species that are adapted to habitats of low organic litter accumulation and coarser substrates (for example, Phragmites versus Typha). With respect to the riparian community, HFE duration affects the amount of scour or burial taking place along the Colorado River channel and initiates post-flood vegetation recovery dynamics between clonal and seed-based plant species. Timing and frequency of HFEs further influence the dynamics occurring between clonal and seed-based species.

\section{Conclusion}

The 2008 HFE provided an opportunity to examine the effects of high flows on riparian vegetation, particularly the susceptibility of native riparian plant communities to the invasion of nonnative species such as tamarisk (Tamarix sp.). The data collected in association with the 2008 HFE suggest that areas subject to intermittent disturbance, such as the LRZ, may be most susceptible to nonnative introductions. Tamarisk seedling germination was relatively minor (less than $2 \%$ of measured cover) 6 months after the experiment. Conducting the 2008 HFE in March likely reduced 
successful tamarisk seedling germination because tamarisk produces flowers and seeds from April through September.

Riparian vegetation was generally buried by sand rather than being removed from the ground by the HFE. Vegetative cover in areas above the highest water level reached during the HFE did not change significantly as a result of the March experiment. The continued coarsening of sandbars relative to pre-dam conditions and dam operations that wash finer sediment downstream appears to favor riparian species that grow through vegetative reproduction (clonal species), are adapted to partial burial, and that can persist in coarser sand, including many native species (for example, arrowweed (Pluchea sericea), seepwillow (Baccharis emoryi), and common reed (Phragmites australis)). Shorter duration flooding appears to result in the development of a homogeneous riparian plant community with low species richness and diversity.

\section{Acknowledgments}

The Bureau of Reclamation provides financial support derived from power revenues to the Grand Canyon Monitoring and Research Center for the science activities it undertakes on behalf of the Glen Canyon Dam Adaptive Management Program. This report was improved by the comments of two reviewers. Field and logistics assistance was provided by April Johnson, Jill Rundall, Bryan Smith, Carol Fritzinger, and Humphrey Summit Support.

\section{References Cited}

Amsberry, L., Baker, M.A., Ewanchuk, P.J., and Bertness, M.D., 2000, Clonal integration and expansion of Phragmites australis: Ecological Applications, v. 10, p. 1110-1118.

Andrews, E.D., 1991, Sediment transport in the Colorado River Basin, in Marzolf, G.R., ed., Colorado River ecology and dam management: Washington, D.C., National Academy Press, p. 5474.

Beauchamp, V.B., and Stromberg, J.C., 2008, Changes to herbaceous plant communities on a regulated desert river: River Research and Applications, v. 24, p.754-770.

Birken, A.S., and Cooper, D.J., 2006, Processes of Tamarix invasion and floodplain development along the Lower Green River, Utah: Ecological Applications, v. 16, p. 1103-1120.

Braun-Blanquet, J., 1965, Plant sociology: the study of plant communities: London, Hafner Publishing, $439 \mathrm{p}$.

Brown, D.E., 1982, Biotic communities of the American Southwest-United States and Mexico: Desert Plants: Salt Lake City, Utah, University of Utah Press, v. 4, nos. 1-4, 342 p.

Carothers, S.W., and Brown, B.T., 1991, The Colorado River through Grand Canyon—natural history and human change: Tucson, University of Arizona Press, $235 \mathrm{p}$.

Clover, E.U., and Jotter, L., 1944, Floristic studies in the canyon of the Colorado and tributaries: American Midland Naturalist, v. 32, p. 591-642.

Cooper, D.J., Andersen, D.C., and Chimner, R.A., 2003, Multiple pathways for woody plant establishment on floodplains at local to regional scales: Journal of Ecology, v. 91, p. 182-196.

Elzinga, C.L., Salzer, D.W., Willoughby, J.W., and Gibbs, J.P., 2001, Monitoring plant and animal populations: Malden, Mass., Blackwell Science, Inc., 360 p.

Fairley, H.C., 2005, Cultural resources in the Colorado River corridor, in Gloss, S.P., Lovich, J.E., and Melis, T.S., eds., The state of the Colorado River ecosystem in Grand Canyon: U.S. Geological Survey Circular 1282, p. 177-192. 
Farrer, E., and Goldberg, D.E., 2009, Litter drives ecosystem and plant community changes in cattail invasion: Ecological Applications, v. 19, p. 398-412.

Franz, E.H., and Bazzaz, F.A., 1977, Simulation of vegetation response to modified hydrologic regimes_probabilistic model based on niche differentiation in a floodplain forest: Ecology, v. 58, p. 176-183.

Gaskin, J.F., and Schaal, B.A., 2002, Hybrid Tamarix widespread in the U.S. invasion and undetected in native Asian range: Proceedings of the National Academy of Sciences, v. 99, p. 11256-11259.

Gladwin, D.N., and Roelle, J.E., 1998, Survival of plains cottonwood (Populus deltoides subsp. monilifera) and salt cedar (Tamarix ramisissima) seedlings in response to flooding: Wetlands, v. 18, p. 669-674.

Graf, W.L., 1978, Fluvial adjustments to the spread of tamarisk (Tamrix chinensis) in the Colorado Plateau region: Bulletin of the Geological Society of America, v. 89, p. 1491-1501.

Griffiths, P.G., Webb, R.H., and Melis, T.S., 1996, Initiation and frequency of debris flows in Grand Canyon, Arizona: U.S. Geological Survey Open-File Report 96-491, 35 p.

Hazel, J.E., Jr., Kaplinski, M., Parnell, R., Kohl, K., and Topping, D.J., 2006, Stage-discharge relations for the Colorado River in Glen, Marble, and Grand Canyons, Arizona: U.S. Geological Survey Open-File Report 2006-1243, 7 p.

Hazel, J.E., Jr., Kaplinski, M., Parnell, R., Manone, M., and Dale, A., 1999, Topographic and bathymetric changes at thirty-three long-term study sites, in Webb, R.H., Schmidt, J.C., Marzolf, G.R., and Valdez, R.A., eds., The controlled flood in Grand Canyon: Washington, D.C., American Geophysical Union, Geophysical Monograph Series, v. 110, p. 161-183.

Hereford, R., Fairley, H.C., Thompson, K.S., and Balsom, J.R., 1993, Surficial geology, geomorphology, and erosion of archeologic sites along the Colorado River, eastern Grand Canyon, Grand Canyon National Park, Arizona: U.S. Geological Survey Open-File Report 93-517, 46 p.

Hupp C.R., and Osterkamp W.R., 1996, Riparian vegetation and fluvial geomorphic processes: Geomorphology, v. 14, p. 277-295.

Kaplinski, M., Behan, J., Hazel, J.E., Jr., Parnell, R.A., and Fairley, H.C., 2005, Recreational values and campsites in the Colorado River ecosystem, in Gloss, S.P., Lovich, J.E., and Melis, T.S., eds., The state of the Colorado River ecosystem in Grand Canyon: U.S. Geological Survey Circular 1282, p. 193-205.

Kearsley, M.J.C., 2006, Vegetation dynamics, in Kearsley, M.J.C., Cobb, N.S., Yard, H., Lightfoot, D., Brantley, S., Carpenter, G., and Frey, J., eds., Inventory and monitoring of terrestrial riparian resources in the Colorado River corridor of the Grand Canyon, an integrative approach-final report: Flagstaff, Ariz., Northern Arizona University, submitted to U.S. Geological Survey, Grand Canyon Monitoring and Research Center, cooperative agreement no. 01 WRAG 0044 (NAU) and 01 WRAG 0034 (HYC), p. 177-199.

Kearsley, M.J.C., and Ayers, T.J., 1999, Riparian vegetation responses - snatching defeat from the jaws of victory and vice versa, in Webb, R.H., Schmidt, J.C., Marzolf, G.R., and Valdez, R.A., eds., The controlled flood in Grand Canyon: Washington, D.C., American Geophysical Union, Geophysical Monograph Series, v. 110, p. 309-328.

Kenkel, N.C., and Podani, J., 1991, Plot size and estimation efficiency in plant community studies: Journal of Vegetation Science, v. 2, p. 539-544.

Korman, J., Wiele, S.M., and Torizzo, M., 2004, Modelling effects of discharge on habitat quality and dispersal of juvenile humpback chub (Gila cypha) in the Colorado River, Grand Canyon: River Research and Applications, v. 20, p. 379-400. 
Lite, S.J., Bagstad, K.J., Stromberg, J.C., 2005, Riparian plant species richness along lateral and longitudinal gradients of water stress and flood disturbance, San Pedro River, Arizona, USA: Journal of Arid Environments, v. 63, p. 785-813.

Malanson, G.P., 1993, Riparian landscapes: Cambridge, Cambridge University Press, 296 p.

Merritt D.M., and Wohl, E.E., 2002, Processes governing hydrochory along rivers: hydraulics, hydrology, and dispersal phenology: Ecological Applications, v. 12, p. 1071-1087.

Merritt D.M., and Wohl, E.E., 2006, Plant dispersal along rivers fragmented by dams: River Research and Applications v. 22, p. 1-26.

Molles, M.C., Crawford, C.S., Ellis, L.M., Valett, H.M., and Dahm, C.N., 1998, Managed flooding for riparian ecosystem restoration: BioScience, v. 48, p. 749-756

Naiman, R.J., and Decamps, H., 1997, The ecology of interfaces-riparian zones: Annual Review of Ecology and Systematics v. 28, p. 621-658.

Naiman, R.J., Decamps, H., and McClain, M.E., eds., 2005, Riparia-ecology, conservation, and management of streamside communities: Amsterdam, Elsevier Academic Press, 448 p.

Nilsson, C., Grelsson, G., Johansson, M., and Sperens, U., 1989, Patterns of plant species richness along riverbanks: Ecology, v. 70, p. 77-84.

Parnell, R.A., Jr., Bennett, J.B., and Stevens, S.E., 1999, Mineralization of riparian vegetation buried by the 1996 controlled flood, in Webb, R.H., Schmidt, J.C., Marzolf, G.R., and Valdez, R.A., eds., The controlled flood in Grand Canyon: Washington, D.C., American Geophysical Union, Geophysical Monograph Series, v. 110, p. 225-239.

Patten, D.T., and Stevens, L.E., 2001, Restoration of the Colorado River ecosystem using planned flooding: Ecological Applications, v. 11, p. 633-634.

Poff, N.L., Allan, J.D., Bain, M.B., Karr, J.R., Prestegaard, K.L., Richter, B.D., Sparks, R.E., and Stromberg, J.C., 1997, The natural flow regime - a paradigm for river conservation and restoration: Bioscience, v. 47, p. 769-784.

Porter, M.E., 2002, Riparian vegetation responses to contrasting managed flows of the Colorado River in Grand Canyon, Arizona: Flagstaff, Northern Arizona University, M.S. thesis, 33 p.

Ralston, B.E., 2005, Riparian vegetation and associated wildlife, in Gloss, S.P., Lovich, J.E., and Melis, T.S., eds., The state of the Colorado River ecosystem in Grand Canyon: U.S. Geological Survey Circular 1282, p. 103-121.

Ralston, B.E., Davis, P.A., Weber, R.M., and Rundall, J.M., 2008, A vegetation database for the Colorado River ecosystem from Glen Canyon Dam to the western boundary of Grand Canyon National Park, Arizona: U.S. Geological Survey Open-File Report 2008-1216, 37 p.

Reisner, M., 1993, Cadillac Desert - the American West and its disappearing water: New York, Penguin Books, 554 p.

Robinson, C.T., and Uehlinger, U., 2003, Using artificial floods for restoring river integrity: Aquatic Science, v. 65, p. 181-182.

Rood, S.B., Gourley, C., Ammon, E.M., Heki, L.G., Klotz, J.R., Morrison, M.L., Mosley, D., Scoppettone, G.G., Swanson, S., and Wagner, P.L., 2003, Flows for floodplain forests-successful riparian restoration along the lower Truckee River, Nevada, USA: BioScience, v. 53, p. 647-656.

Rubin, D.M., Schmidt, J.C., and Moore, J.N., 1990, Origin, structure and evolution of a reattachment bar, Colorado River, Grand Canyon, Arizona: Journal of Sedimentary Petrology, v. 60, p. 982-991.

Rubin, D.M., Topping, D.J., Schmidt, J.C., Hazel, J., Kaplinski, K., and Melis, T.S., 2002, Recent sediment studies refute Glen Canyon Dam hypothesis: EOS, Transactions, American Geophysical Union, v. 83, n. 25, p. 273, 277-278. 
Schmidt, J.C., Andrews, E.D., Wegner, D.L., Patten, D.T., Marzolf, G.R., and Moody, T.O., 1999, Origins of the 1996 controlled flood in Grand Canyon, in Webb, R.H., Schmidt, J.C., Marzolf, G.R., and Valdez, R.A., eds., The controlled flood in Grand Canyon: Washington, D.C., American Geophysical Union, Geophysical Monograph Series, v. 110, p. 23-36.

Schmidt, J.C., and Graf, J.B., 1990, Aggradation and degradation of alluvial-sand deposits, 1965 to 1986, Colorado River, Grand Canyon National Park, Arizona: U.S. Geological Survey Professional Paper 1493, 74 p.

Schmidt, J.C., Topping, D.J., Grams, P.E., and Hazel, J.E., 2004, System-wide changes in the distribution of fine sediment in the Colorado River corridor between Glen Canyon Dam and Bright Angel Creek, Arizona-final report submitted to the Grand Canyon Monitoring and Research Center: Logan, Utah, Utah State University, 107 p.

Sher, A.A., and Marshall, D.L., 2003, Competition between native Populus deltoides and invasive Tamarix ramosissima and the implications of reestablishing flooding disturbance: Conservation Biology, v. 14, p. 1744-1754.

Sher, A.A., Marshall, D.L., and Taylor, J.P., 2002, Establishment patterns of native Populus and Salix in the presence of invasive, non-native Tamarix: Ecological Applications, v. 12, p. 760-772.

Stevens, L.E., 1989a, Mechanisms of riparian plant community organization and succession in the Grand Canyon, Arizona: Flagstaff, Northern Arizona University, Ph.D. dissertation, 124 p.

Stevens, L.E., 1989b, The status of ecological research on tamarisk (Tamaricaceae: Tamarix ramosissima) in Arizona, in Kunzman, M.R., Johnson, R.R., and Bennett, P.S., eds., Proceedings of Tamarisk control in Southwestern United States-special report no. 9: Tucson, National Park Service, Cooperative National Park Resources Studies Unit, University of Arizona, p. 99-105.

Stevens, L.E., Schmidt, J.C., Ayers, T.J., and Brown, B.T., 1995, Flow regulation, geomorphology, and Colorado River marsh development in the Grand Canyon, Arizona: Ecological Applications, v. 5, p. 1025-1039.

Stevens, L.E., Shannon, J.P., and Blinn, D.W., 1997, Colorado River benthic ecology in Grand Canyon Arizona, USA — dam, tributary and geomorphological influences: Regulated Rivers: Research and Management, v. 13, p. 129-149.

Stevens, L.E., and Waring, G.L., 1986, Effects of post-dam flooding on riparian substrates, vegetation and invertebrate populations in the Colorado River corridor in Grand Canyon, Arizona: U.S. Bureau of Reclamation, Glen Canyon Environmental Studies, contract no. IA4-AA40-01930, GCES 19/87, $175 \mathrm{p}$.

Stromberg, J., 1998, Dynamics of Fremont cottonwood (Populus fremontii) and salt cedar (Tamarix chinensis) populations along the San Pedro River, Arizona: Journal of Arid Environments, v. 40, p. 133-155.

Stromberg, J., 2001, Restoration of riparian vegetation in the Southwestern United Statesimportance of flow regimes and fluvial dynamism: Journal of Arid Environments, v. 49, p. 17-34.

Tabacchi, E., Correll1, D.L., Hauer, R., Pinay, G., Planty-tabacchi, A., and Wissmar, R.C., 1998, Development, maintenance and role of riparian vegetation in the river landscape: Freshwater Biology, v. 40, p. 497-516.

Thébaud, C., and Debussche, M., 1991, Rapid invasion of Fraxinus ornus L. along the Herault River system in southern France - the importance of seed dispersal by water: Journal of Biogeography, v. 18, p. 7-12.

Topping, D.J., Rubin, D.M., Nelson, J.M., Kinzel, P.J., III, and Bennett, J.P., 1999, Linkage between grain-size evolution and sediment depletion during Colorado River floods, in Webb, R.H., Schmidt, 
J.C., Marzolf, G.R., and Valdez, R.A., eds., The controlled flood in Grand Canyon: Washington, D.C., American Geophysical Union, Geophysical Monograph Series, v. 110, p. 71-98.

Topping, D.J., Rubin, D.M., Schmidt, J.C., Hazel, J.E., Jr., Melis, T.S., Wright, S.A., Kaplinski, M., Draut, A.E., and Breedlove, M.J., 2006, Comparison of sediment-transport and bar-response results from the 1996 and 2004 controlled-flood experiments on the Colorado River in Grand Canyon: Federal Inter-Agency Sedimentation Conference, 8th, Reno, Nevada, 2006, CD-ROM Proceedings (ISBN 0-9779007-1-1).

Topping, D.J., Rubin, D.M., and Vierra, L.E., Jr., 2000, Colorado River sediment transport 1—natural sediment supply limitation and the influence of Glen Canyon Dam: Water Resources Research, v. 36, p. 515-542.

Topping, D.J., Schmidt, J.C., and Vierra, L.E., Jr., 2003, Computation and analysis of the instantaneous-discharge record for the Colorado River at Lees Ferry, Arizona-May 8, 1921, through September 30, 2000: U.S. Geological Survey Professional Paper 1677, 118 p.

Tuchman, N.C., Larking, D.J., Geddes, P., Radka, W, Jankowski, K., and Goldberg, D.E., 2009, Patterns of environmental change associated with Typha X glauca invasion in a Great Lakes coastal wetland: Wetlands, v. 29, p. 964-975.

Turner, R.M., and Karpiscak, M.M., 1980, Recent vegetation changes along the Colorado River between Glen Canyon Dam and Lake Mead, Arizona: U.S. Geological Survey Professional Paper 1132. $125 \mathrm{p}$.

U.S. Department of Agriculture, 2010, The PLANTS Database: Baton Rouge, La., National Resources Conservation Service [http://plants.usda.gov/].

U.S. Department of the Interior, 1995, Operation of Glen Canyon Dam Final Environmental Impact Statement: Salt Lake City, Utah, Bureau of Reclamation, Upper Colorado Region, 337 p.

U.S. Department of the Interior, 1996, Record of Decision, Operation of Glen Canyon Dam Final Environmental Impact Statement: Washington, D.C., Office of the Secretary of Interior, 15 p.

U.S. Geological Survey, 2007, Science plan for potential 2008 experimental high flow at Glen Canyon Dam: Flagstaff, Ariz., Southwest Biological Science Center, Grand Canyon Monitoring and Research Center, 104 p.

Valdez, R.A., Carothers, S.W., House, D.A., Douglas, M.E., Douglas, M., Ryel, R.J., Bestgen, K.R., and Wegner, D.L., 2000, A program of experimental flows for endangered and native fishes of the Colorado River in Grand Canyon - final report to U.S. Department of Interior, Grand Canyon Monitoring and Research Center, Flagstaff, Ariz.: Flagstaff, Ariz., SWCA, Inc. Environmental Consultants, $68 \mathrm{p}$.

Waring, G.L., 1995, Current and historical riparian vegetation trends in Grand Canyon, using multitemporal remote sensing analyses of GIS sites - final report: National Park Service, submitted to U.S. Bureau of Reclamation, Glen Canyon Environmental Studies and Northern Arizona University, cooperative agreement no. CA 8000-8-0002, 24 p.

Webb, R.H., Melis, T.S., and Valdez, R.A., 2002, Observations of environmental change in Grand Canyon: U.S. Geological Survey Water Resources Investigations Report 02-4080, 33 p.

Webb, R.H., Schmidt, J.C., Marzolf, G.R., and Valdez, R.A., eds., 1999, The controlled flood in Grand Canyon: Washington, D.C., American Geophysical Union, Geophysical Monograph Series, v. $110,367 \mathrm{p}$.

Wright, S.A., Melis, T.S., Topping, D.J., and Rubin, D.M., 2005, Influence of Glen Canyon Dam operations on downstream sand resources of the Colorado River in Grand Canyon, in Gloss, S.P., Lovich, J.E., and Melis, T.S., eds., The state of the Colorado River ecosystem in Grand Canyon: U.S. Geological Survey Circular 1282, p. 17-31. 
Wright, S.A., Schmidt, J.C., Melis, T.S., Topping, D.J. and Rubin, D.M., 2008, Is there enough sand? Evaluating the fate of Grand Canyon sandbars: Geological Society of America Today, v. 18, p.410. 


\section{Appendix - List of species encountered in April and September 2008}

\section{Species name_common name}

Abronia elipitica-sand verbena

Acacia greggii-catclaw acacia

Agave utahensis - century plant

Agoseris sp.--agoseris

Agrostis stolonifera-bent grass

Alhagi maurorum — camelthorn

Ambrosia acradenia-ragweed

Amsinkia menziesii.-fiddleneck

Anemone tuberose-desert windflower

Andropogon gerardii-big bluestem

Arabis tournefortii-Saharan mustard

Artemesia dracunculoides-sage

Artemesia ludoviciana-sage

Aristida purpurea-three awn grass

Astragalus sp.-milkvetch

Atrichoseris platyphylla-gravel ghost

Atriplex canascens-four-wing salt bush

Baccharis emoryi-Emory's seepwillow

Baccharis salicifolia-seepwillow

Bacharis sarathroides-desert broom

Baccharis sergiloides-desert baccharis

Bebbia juncia-chuckwalla's delight

Bothriochloa barbinodis-goats beard

Boutelua curtipendula-side oats grama

Brickellia californica-California brickelbush

Brickellia longifolia-long-leaf brickelbush

Bromus diandrus_-ripgut grass

Bromus inermus-smooth brome

Bromus rubens-red bome

Bromus tectorum-cheat grass

Carex aquatilis-leafy sedge

Calochortus flexuosus-mariposa lily

Centarurium arizonicum-Arizona centaury

Cheanactis stevioides-desert pincushion

Chlorocantha spinosa-spiny aster

Cladium californicum — sawgrass

Cryptantha sp.-Cryptantha

Cynodon dactylon-Bermuda grass

Dalea albiflora-whiteflower prairie clover
Species name-common name

Datura wrightii-jimson weed/sacred datura

Dicoria canescens-desert dicoria

Draba sp.-mustard

Echinocereus triglochidiatus-claret cups

Eleagnus angustifolia-Russian olive

Eleocharis sp.—spike rush

Elymus Canadensis-Canadian wheatgrass

Encelia farinose-brittlebush

Ephedra nevadensis-mormon tea

Equisetum arvense-scouring rush

Equisetum ferrisii-horsetails

Eragrastis ciliate-stink grass

Eriastrum diffusum-diffuse eriastrum

Erigeron sp.-fleabane

Eriogonum inflatum-desert trumpet

Erodium circutarium-filaree

Eucrypta micrantha-small-flowered

eucrpyta

Euthamia occidentalis-western goldenrod

Fallugia paradoxa-apache plume

Funastrum cynanchoides-twining

milkweed

Gallium stellatum-bedstraw

Gilia ophthalmoides_eyed gilia

Gutterizia sarathrae-snakeweed

Hesperostipa comata-needle and thread

Imperata brevifolia-satintail

Isacoma acradenia-jimmyweed

Juncus sp.-rush

Kramaria erecta-littleleaf ratany

Langloisia setosissima-moth langloisia

Lappula sp.-American stickseed

Larrea tridentate-creosote bush

Lepidium fremontii-desert pepperweed

Lepidium latifolia-broadleaved

pepperweed

Lepidium montanum-mountain

pepperweed

Linanthus bigelovii-Bigelow's linanthus

Lolium perenne-perennial rye grass

Lycium sp.-desert thorn 


\section{Species name - common name}

Macaranthera canescens-aster Malacothrix glabrata-smooth desert dandelion Mammalaria grahamii-fishhook cactus Maurandella antirhinafolium - twining snapdragon

Mentha arvense-common mint Mentzelia pumila-stickleaf

Melilotus officianale-sweet clover Muhlenbergia asperifolia-scratchgrass Myosotis sp.-forget-me-not Nasturium officinale-watercress Nemocladus glandulifera-glandular threadlant

Nicotiana glauca-wild tobacco

Nolina microcarpa-beargrass Oenothera caespitosa-tufted evening primrose

Oenothera elata-Hooker's evening primrose

Oenothera pallid-pale-evening primrose

Opuntia basilaris-beavertail cactus Opuntia phaeacantha-brown-spined prickly-pear

Cylindropuntia acanthocarpa —cholla Achnatherum hymenoides-Indian rice grass

Panicum capillare — witch grass

Phragmites australis-river cane

Phlox sp-phlox

Piptatherum miliaceum —smilograss

Piptochaetium setosum — bristly spear grass

Plantago lancelata-lanceleaf plantain

Plantago major-common plantain

Plantago ovate-blond plantain

Pleuraphis jamesii-galleta grass

Pluchea sericea-arrowweed

Populus fremontii-freemont cottonwood

Porophyllum gracilis-poor weed

Polypogon monspilienses—rabbitfoot grass

\section{Species name-common name}

Prosopis glandulosa-mesquite Psorothamnus arborescens-Mojave indigobush

Psuedognaphalium stramineum-cudweed Purshia subintegra-cliff rose Rannunculus sp.-buttercup Salix exigua-coyote willow Salix goodingii-Goodings willow Salsola tragus-Russian thistle Schoenoplectis sp.-bulrush Schismus sp.-Mediterranean grass Shizachyrium scoparium -little bluestem Sonchus asper-spiny sow thistle Sonchus oleracea-sow thistle Solidago occidentalis-goldenrod Sphaeralcea ambigua-globe mallow Sporobolus contractus-spike dropseed Sporobolus cryptandrus-sand dropseed Sporobolus flexuus-mesa dropseed Sporobolus giganteus-giant dropseed Stellaria longipes-longstalk starwort Stephanomeria pauciflora-wire lettuce Stanleya pinnatifida-Prince's plume Streptanthella longirostris-long-beaked twist flower

Stylocline micropoides-desert nest-straw

Taraxacom officinale-dandelion

Tamarisk sp.-_tamarisk

Thymophylla pentachaeta-dogweed

Trixis californica-trixis

Typha latifolia-cattail

Umbelliferae sp.-wild parsley

Veronica Americana —speedwell

Vicia sp.-vetch

Vulpia octoflora - six weeks fescue

Yucca baileyii-soaptree yucca

Xylorhiza tortifolia-Mojave aster

Ziziphus obtusifolia-graythorn 
This page intentionally left blank 


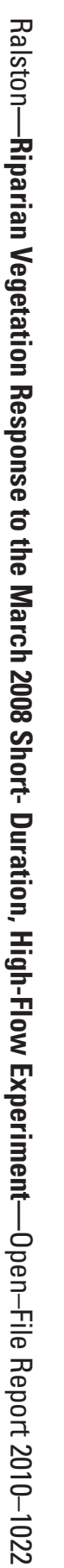

